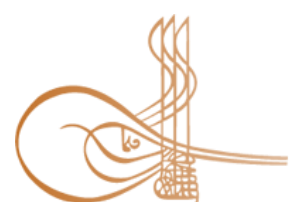

www.turkishstudies.net/history
Turkish Studies - Historical Analysis

eISSN: 2667-5552

Research Article / Araştırma Makalesi

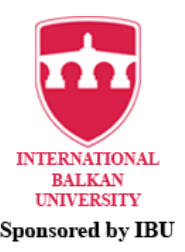

Sponsored by IBU

\title{
İstanbul Boğazı'nda Yaşanan En Büyük Çevre Felaketi: İndependenta-Evriali Çarpışması ve Etkileri (15 Kasım 1979)
}

\author{
The Largest Environmental Disaster In The Bosphorus: Independenta-Evriali Collision And Its \\ Effects (November 15, 1979)
}

Tuğba Belenli*

\begin{abstract}
Romanian flagged "Independenta" tanker and 5,298 tons of Greek flagged "Evriali" freighter collided in the Sea of Marmara on 15 November 1979. This accident is the biggest marine accident in the region. As a result of the accident, while Greek sailors survived, nearly 50 Romanian sailors died by drowning or burning. As a result of the explosion, the windows of many buildings were broken, the Independenta tanker continued to burn for 29 days after the collision, and the people of Istanbul were terrified in this process. The accident caused a lot of financial damage to the fishing industry, leaving irreversible effects in the long term, such as environmental pollution. The Independenta accident is the most "tragic" and "destructive" marine accident in the Turkish Straits, but has increased public awareness of the risks that ships passing through the Straits may pose and initiated discussions to take the necessary measures to prevent accidents in the Straits. Even though the accident was thought to have been overcome, the comments were made in that period, "Istanbul has not experienced such terror, such fear, panic like this." Independenta accident, the most obvious and most dangerous example of the accidents caused by the Bosphorus traffic, threatening the city of Istanbul in such a way, opened the articles of the Montreux Straits Conventionespecially, discussion to leave the option of getting a guide when passing through the Bosphorus- to prevent the protection of the city and similar events in that period. Bringing into the Montreux Agreement question was considered unnecessary and dangerous for some, while the other party argued that it was inevitable.
\end{abstract}

Structed Abstract: Over the years, many serious accidents have occurred in the Turkish Straits, especially at the entrance of the Bosphorus, leading to marine and environmental pollution. These accidents caused casualties and injuries, caused serious ecological damage to the historical seaside and cultural property, marine life and underwater resources, and disrupted marine traffic. Various tanker accidents in the world have caused environmental disasters and threatened the Turkish Straits as a potential danger and caused social turmoil.

The Bosphorus is one of the 265 straits in the World, it is the largest commercial transit route in the world in terms of the average number of ships passing per day. As a result of such intense traffic, between 1953-2002, there were 209 collisions, 138 landings, 77 shots, 28 fires and explosions, and 461 marine accidents, 9 were other types in The Bosphorus.

\footnotetext{
* Dr. Öğr. Üyesi, Gazi Üniversitesi, Eğitim Fakültesi, Türkçe ve Sosyal Bilimler Eğitimi Bölümü, Tarih Eğitimi ABD Asts. Prof., Gazi University, Faculty of Education, Department of Turkish And Social Sciences Education, Department of History Education. 
The accident subject to this study; is a collision between the Romanian Independanta tanker and the Greek Evilya freighter in the Marmara Sea in the south of the Bosphorus, on November 15, 1979, at 5.30. The Independenta-Evriali collision, which is called "Istanbul has not experienced such terror, such fear, such panic like this", is by far the biggest sea accident in the Bosphorus. In addition to being the largest marine accident in Istanbul, it is one of the 20 largest oil spill accidents in the world, causing severe marine and air pollution. In fact, the accident, which could be end in a much more catastrophic way and even cause many civilians to die, has been eluded in the lightest way possible with the help of fortune, while almost all of the Romanian sailors died and all Greek sailors survived. The accident was overcome for the following reasons; Independenta was 2 years old and was a solid tanker, didn not speed up very much during the accident, "Evriali" had a small tonnage, the accident occured just before entering the Bosphorus, the air was breezy and the sea was waveless, and the tanker immediately catched fire and most of the fuel burned and the amount spilled into the sea was relatively low. The fire in the Romanian tanker that burned for 29 days stopped spontaneously with the help of the weather.

Two more eruptions followed after the first and very strong eruption on 15 November on 18 November and 6 December, resulting in more oil spread to the sea. Due to the heat, the stained glass windows of the Haydarpaşa Station melted and the windows of the surrounding buildings were broken, including Topkap1 Palace and the Blue Mosque. In this process, the Ministry of National Education announced that some primary, secondary and high schools were on holiday in Kadıköy, Moda and Fenerbahçe. The Marmara Municipalities Union warned the municipalities on the seashore to warn the public. The Army and Istanbul Martial Law Command issued a statement and informed the public about the measures taken. "Independenta" accident is, the most important environmental pollution accident faced by Turkey. In addition to the fishes that died suddenly with the explosion of the tanker, the crude oil mixed with the sea also damaged the fishes, nests and eggs. With the combustion of oil in the tanker, carbon monoxide, carbon dioxide, hydrocarbons and benzpyrene and similar chemicals, which negatively affect human health, and even cause cancer, have spread to the environment.

As a result of the judicial proceedings, the experts determined that the captain of the Greek freighter was $90 \%$ defective in the accident. A lawsuit was filed against the captain of the Greek freighter in the Kadıköy Assize Court, the captain was received imprisonment for 3 years in prison, and the Greek ship was confiscated. After the accident, was filed a lawsuit against those responsible for the tanker, and \$291,500 was paid to 15 fisheries cooperatives, especially since the fishing nets and boats of those working in the fishing field were damaged. Responsibilities arising from the accident were tried to be dealt with within the narrow-framed articles related to the responsibility of the Turkish Commercial Code. But these articles were also very old and in no way complied with the needs of the day. The existing difficulties and removal of wreck were tried to be solved with the articles of the Maritime Law and the limited articles of the Ports Law.

Although the "Independenta" accident is the most "tragic" and "destructive" marine accident in the Turkish Straits, it has increased public awareness of the risks that ships passing through the Straits might pose and initiated discussions to take the necessary measures to prevent accidents in the Straits.

After the "Independenta" accident, experts asked to come together and work with all authorized institutions for the prevention of accidents in the Bosphorus. One of these precautions is "taking the pilot". "Montreux Convention Regarding the Regime of the Straits" has come into question in favor of Turkey and the replacement of some substances have been proposed. Despite the Montreux Convention, some problems with the Straits are still existing. Hese problems are issues such as taking the necessary precautions and obliging the ships to obey some rules such as "taking the pilot". These problems and discussions, which continue today, seem to have led to projects such as "Kanal Istanbul".

Keywords: History of the Rebuplic of Turkey, Independenta, Evriali, The Republic of Turkey, Montreux Straits Convention, Bosphorus.

Öz: Rumen bandıralı 150 bin tonluk "İndependanta” tankeri ile 5,298 tonluk Yunan bandıralı "Evriali” şilebi 15 Kasım 1979 tarihinde Marmara Denizi'nde çarpışmıştır. Bu kaza, bölgede yaşanmış en büyük deniz kazasıdır. Kaza sonucu Yunan denizciler hayatta kalırken, 50’ye yakın Rumen denizci boğulmak veya yanmak suretiyle hayatlarını kaybetmiştir. Patlama sonucu pek çok binanın camları kırılmış, İndependenta tankeri çarpışmadan sonra 29 gün boyunca yanmaya devam etmiş, bu süreçte İstanbul halkı korku ve dehşete

Turkish Studies - History, 15(2) 
kapılmıştır. Kaza, balıkçılık sektörüne maddi birçok zarar vermiş, çevre kirliliği gibi uzun vadede dönüşü olmayan etkiler bırakmıştır. İndependenta kazası, Türk Boğazlarındaki en "trajik” ve "yıkıcı" deniz kazası olmakla birlikte Boğazlardan geçen gemilerin yaratabileceği riskler karşısındaki kamu farkındalığını arttırarak, Boğazlarda kazaları önlemek için gereken tedbirleri almak için yapılan tartışmaları başlatmıştır. Kazanın kılpayı atlatıldığı düşünülse de, o dönemde "İstanbul İstanbul olalı böyle dehşet böyle korku böyle panik yaşamadı" yorumları yapılmıştır. Boğaz trafiğinin neden olduğu kazaların İstanbul'u böylesine tehdit etmesinin en bariz ve en tehlikeli örneği olan İndependenta kazası, o dönemde şehrin korunması ve benzer olayların yaşanmasını engellemek için Montrö Boğazlar Sözleşmesi'nin maddelerini -özellikle Boğaz'dan geçerken kılavuz almanın tercihe bırakılması maddesini- tartışmaya açmıştır. Montrö Boğazlar Sözleşmesi'nin gündeme getirilmesi kimilerince gereksiz ve tehlikeli bulunmuş, diğer tarafsa bunun kaçınılmaz olduğunu savunmuşlardır.

Anahtar Kelimeler: Türkiye Cumhuriyeti Tarihi, İndependenta, Evriali, Türkiye Cumhuriyeti, Montrö Boğazlar Sözleşmesi, İstanbul Boğazı.

\section{Giriş}

Kazanın yaşandığı Karadeniz ile Ege Denizi arasındaki en önemli ana yol olan İstanbul Boğazı, dünyadaki 265 boğazdan birisidir. Günde 300, yılda 100 bin gemi geçen Malakka Boğazı'ndan sonra günde ortalama, yerel trafik hariçç, 132 geminin geçtiği dünyanın en büyük ticaret arterlerinden biridir. Boğazlar, ekonomik ve stratejik olarak son derece önemli bir geçiş mevkiidir (Akten, 2003: 241). ${ }^{2}$ Burada yaşanacak kazaların maddi ve manevi çok ağır sonuçları olmaktadır.

Boğaz, 1953-2002 yılları arasında, 209 çarpışma, 138 karaya oturma, 77 kıyıya vurma, 28 yangın ve infilak ve 9'u diğer çeşitte (dümen blokajı, geminin yan yatması, motor arızası) olmak üzere 461 deniz kazasıyla yüz yüze gelmiştir (Akten, 2003: 256). ${ }^{3}$ İstanbul Boğazı'ndaki deniz kazaları içinde \%56 ile en çok karaya oturma ve kıyıya çarpma kazaları görülmüştür (Akten, 2003: 258). ${ }^{4}$ Uzmanlar, Boğazlarda yaşanan gemi kazalarının sebeplerini şöyle sıralamaktadır: gemilerin kılavuz almaması, kötü hava şartları, yoğun deniz trafiği, gemilerin teknik yetersizlikleri, Boğaz akıntılarının kompleks ve günden güne değişmesi, bölge hakkında yeterli bilgi olmaması, güvenli geçiş için gerekli uyanıklık ve dikkat kaybı, keskin dönüş gerektiren alanların varlığı, karanlık ve arkaplan kıyı aydınlatmaları, trafik ayırma şemasındaki gemilerin uygunsuz davranışı (Akten, 2003: 262) ve uygun gemi refakat sistemi eksikliği (Akten, 2002: 190). ${ }^{5}$

\footnotetext{
${ }^{1}$ Yerel trafik de düşünülürse bu sayılara günde 2 bin geçiş daha eklenmelidir (Akten, 2002: 188). 1977 ve 1978 verilerine göre, Boğazlardan günde yaklaşık 100, bir yılda ortalama 30 bin gemi geçiş yapmaktadır. (Bugün, 4.12.1979: 2) 1978 yılında Boğazlardan 18,792 gemi, ayda 1,566, günde ise 52,2 gemi geçmiştir (Cumhuriyet Senatosu Tutanak Dergisi, 20.11.1979: 97, 98).

${ }^{2}$ İstanbul Boğazı, 31,7 km. uzunluğunda, kuzey girişinde en geniş noktada 4,7 km., güney girişinde 2,5 km. genişliğindedir. Dünyadaki en dar Boğaz olarak bilinmektedir ve en dar noktası Kandilli-Rumelihisarı-Bebek hattında olup 698 metredir. Derinlik 30 ve 60 metre arasında değişmekte olup en derin yeri Kandilli'de 110 metredir. İstanbul Boğazı'nda 12 keskin dönüş noktası vardır. Denizbilimsel olarak boğazı etkileyen en önemli faktör, dalgalar ya da gelgit değil akıntılardır. Boğaz'ın dar ve bükümlü yapısı akımların etkisini arttırmaktadır. Yıllık yaklaşık 55 bin gemi geçmekte, günde 2 milyona yakın insan işe feribot ve özel teknelerini kullanarak bu yoldan gitmektedir (Birpınar, Talu, Su, Gülbey, 2006: 2; Usluer, Alkan, 2016: 3, 18)

3 İstanbul Boğazı'nda 1948-1982 yılları arasında 113, 1982-1994 yılları arasında 208 ve 1997-2003 arasında 358 kaza yaşanmıştır (Birpınar, Talu, Su, Gülbey, 2006: 6). Cumhuriyet Senatosu'nda kazayla ilgili konuşan Oramiral Hilmi Fırat, 1960-1977 yılları arasında Boğazlarda 17 çarpışma, 3 önemli akaryakıt yangını ve 50 karaya oturma ve sahile bindirme vakası olduğunu söylemiştir (Cumhuriyet Senatosu Tutanak Dergisi, 20.11.1979: 97, 98). Başka bir kaynağa göre, Marmara Denizi ve İstanbul Boğazı'nda 1949-1999 yılları arasında 50 yılda 292 deniz kazası meydana gelmiştir (Milliyet, 23.1.1999: 13). 1948-2001 yılları arasındaki 113 kazanın listesi için bakınız; Topakoğlu, 2004: 104-124).

${ }^{4}$ Genel olarak deniz kazalarının meydana gelme sebepleri şöyledir; \%36,7 karaya oturma, \%26,6 çarpışma, \% 11,4 patlama, $\% 7,5$ su sızması, \%5,7 yapı hataları, \%3,6 yangın, \%2,0 yükleme-boşaltma, \%6,5 çeşitli (Hürriyet, 9.11.1979: 5).

${ }^{5}$ Bir gazete haberinde, gemicilerin "korkulu geçit” adını verdikleri İstanbul Boğazı'nda kazaların şu sebeplerden olduğu yazılmıştır; 1. Şiddetli lodos, 2. Kesif sis, 3. Yabancı gemilerin kılavuz kaptan almaması (Milliyet, 22.3.1982: 11).
} 
Marmara Denizi'nde, 15 Kasım 1979 tarihinde İstanbul Boğazı'nın güney yakınlarında sabah saat 5.30'da bir patlama meydana gelmiş, liman yetkilileri öncesinde imdat çağrısı aldıklarını fakat kurtarma gemileri ulaşamadan patlamanın yaşandığını bildirmişlerdir (Barış, 16.11.1979: 1). Duyulan patlama Rumen İndependanta tankeri ile Yunan Evriali şilebinin çarpışmasıdır. Kazaya karışan Rumen İndependenta tankeri Romanya'nın bağımsızlığının 100. yıldönümü nedeniyle denize indirilmiş oldukça büyük bir tankerdir. ${ }^{6}$ Kaza sırasında Libya'dan Köstence'ye 95 bin ton ham petrol götürmektedir. Evriali ise, su borusu taşıyan 5,298 tonluk bir Yunan yük gemisidir (The Times, 16.11.1979: 7), ${ }^{7} 7,400$ ton çeliği Zhdanov'dan Akdeniz'e götürmektedir (Usluer, Oğuzülgen, 2018: s. 7). İndependenta, İstanbul Boğazı'na girmek üzere ilerlerken Haydarpaşa dalgakıranının 4 mil yakınında Yunan Evriali şilebiyle çarpışmıştır. İndependenta, kazadan önce sürekli alarm düdüğü çalmış ve 8 kere "SOS" vermiştir (Tercüman, 16.11.1979: 12).

Dünyanın en yoğun gemi trafiğginden birine sahip Boğaz'da meydana gelen bu kaza bir dizi patlamaya neden olmuş ve bu patlamalarda 4 mil çevredeki binaların camları paramparça olmuştur. Sonrasında deniz yüzeyine yayılan petrol nedeniyle görülen parlamalar, kurtarma girişimlerini engellemiştir (International Herald Tribune, 16.11.1979: 2). O dönemde, kazanın çok daha büyük felaketlere yol açmayıp kılpayı atlatıldığı düşünülmüştür. İndependenta'nın 2 yaşında ve sağlam bir tanker olması, kaza sırasında çok hız yapmıyor olması, Evriali'nin küçük tonajlı olması (Milliyet, 17.11.1979: 9; Hürriyet, 17.11.1979: 1), kazanın Boğaz'a girilmeden hemen önce yaşanması (Kutluk, 2003: 10), ${ }^{8}$ havanın esintisiz ve denizin dalgasız olması (Milliyet, 16.11.1979: 1), tankerin derhal alev almasıyla yakıtın büyük kısmının yanarak duman halinde dağılması ve denize dökülen miktarın nispeten az olması (Yücesan, 1980: 6), muhtemel daha büyük bir felaketi önlemiştir. 29 gün boyunca süren Rumen tankerindeki yangın, şiddetli firtınanın etkisiyle birdenbire durmuştur (Hürriyet, 15.11.1979: 1).

\section{Kazadan Sonra Yaşananlar}

Kazadan üç gün sonra İndependenta hâlâ yanmaktadır. Geminin patlama riski, alevler tankerdeki 95 bin tonluk ham petrole ulaşınca tekrar artmıştır. Mürettebattan sadece üç kişi kendisini tankerden kurtarabilmiştir (Die Welt, 19.11.1979: 20). İstanbul limanı yakınındaki sokaklar, büyük alevler püskürten tankerin patlama riskinden çekinildiği için askerler tarafindan boşaltılmıştır. Gemi bordasında petrol bulunan tanker, İstanbul Boğazı'nın ağzında Yunan şilebiyle çarpıştığı andan itibaren yanmaya devam etmiştir. Çevre Bakanı M. Orhan Eren, bu kazanın çevreye çok büyük zararlar verdiğini ifade etmiştir. Marmara Denizi’nin güneyinde deniz yüzeyine çok miktarda petrol

\footnotetext{
${ }^{6}$ İndependenta, 1978 yılında denize indirilmiş yeni bir gemidir. Yüksüz 147,631 ton ağırlığında, 283 metre uzunluğunda, 46 metre geniş̧liğinde, üst güverte hariç 22 metre derinliğindedir. Kaza sirasında yükü tamamen dolu değildir, 96 bin ton ham petrol taşımaktadır (Usluer, Oğuzülgen, 2018: 7). İndependenta'nın inşasına Köstence donanma tersanesinde 22 Temmuz 1976'da başlanmış, inşası 10 ay devam etmiştir. 150 bin DW tonluk ağırlığı ile Romanya'da o tarihe kadar yapılmış en büyük gemidir. Geminin vaftiz törenini 27 Mayıs 1977'de diktatör çift Nicolae ve Elena Ceausescu yapmıştır. Elena Causescu'nun şampanya patlatma girişimi başarısızlıkla sonuçlanmış bu da kötü bir işaret ve lanet olarak görülmüştür. Boğaziçi’nden Karadeniz’e geçmeyi beklerken yaşanan kaza, geminin 19. seferidir. İndependenta, Rumen filosunun "Titanic"idir. (http://www.marinarii.ro/nave-de-istorie.php?id=2\&name=Nava_Independenta). Rumenler, bu tankeri uğursuz görmüşler, Osmanlı'dan ayrılışın 100. yılında yapılan "tankerin her an kaza yapmasını bekliyorduk" demişlerdir (Hürriyet, 17.11.1979: 13).

${ }^{7}$ Dışişleri eski Bakanlarından Cumhuriyet Senatosu Başkanı İhsan Sabri Çağlayangil bir gazetecinin sorduğu "Boğazlarda özellikle Yunan gemilerinin kaza yapması, bazı yorumlara neden oluyor. Yunanlılar'ın Boğazların statüsünün değiştirilmesi için ortam yaratmak istedikleri ileri sürülüyor. Bu konuda görüşünüz nedir?” sorusuna “Bu konuda yorum yapamam” şeklinde cevap vermiştir (Barış, 17.11.1979: 4).

8 Oramiral Hilmi Fırat’a göre; “Bu çarpışma Haydarpaşa açıkları yerine, 4-5 mil daha kuzeyde mesela Üsküdar, Dolmabahçe, Ortaköy veya İstinye önlerinde vaki olsaydı her halde İstanbul şehri ve limanı dünyada misli görülmemiş bir yangına maruz kalır, yine bu şehrimiz dolayısılla ülkemiz gerek maddi, gerek manevi bakımdan büyük ölçüde can ve mal kaybına maruz kaldırd."” (Cumhuriyet Senatosu Tutanak Dergisi, 20.11.1979: 97) Yenal'a göre de; "Eğer Rumen tankeri kazası Boğaz köprüsü civarında olsa idi, köprü elden çıkar, Beylerbeyi Sarayı yanardı. Kaza sonunda şehrin ulaşımı yıllarca sekteye uğrar ve tarihi bir abide yerine konamazd. Bu ă̆ır zarar kulüp sigortası ile falan telafi edilemezdi." (Tercüman, 27.11.1979: 2)
}

Turkish Studies - History, 15(2) 
tabakası yayılmış ve binlerce ölü balık dalgalar tarafında kıyıya sürüklenmiştir (The Times, 19.11.1979: 5).

Kazadan sonra Beşiktaş önlerine demirlenen Evriali arka tarafındaki halatın kopması üzerine yakınındaki “Akdeniz” gemisine çarpmış (Milliyet, 5.12.1980: 7), burada kaldığı süre boyunca da hurda demir çalanların uğrak yeri olmuştur (Milliyet, 24.3.1981: 10). Aynı şekilde İndependenta da çeşitli zamanlarda hırsızların istilasına uğramış, bir keresinde dört ton ağırlığındaki ve yaklaşık yarım milyon değerindeki zinciri kaynak tüpleriyle kesip götürmek isteyen hırsızlar polisi görünce kaçmışlardır (Milliyet, 14.7.1981: 3; Milliyet, 16.6.1982: 1). İndependeta'nın enkazı Haydarpaşa'da y1llarca kalmaya devam ederek diğer gemilere sorun yaratmaya devam etmiştir. Örneğin "Hürriyet" isimli araba feribotu 19 Nisan 1983'de enkaza çarparak hasara uğramıştır. İstanbul şehri, bu kazadan 7 yıl sonra enkazdan kurtulabilmiştir (Usluer, Oğuzülgen, 2018: 7).

Yunan şilebi ve Rumen tankerinin çarpışması sonrasında yaşanan patlama neticesinde en az 50 insan kaybolmuş ve zaten en baştan itibaren bunların tankerden sağ çıkamayacağ 1 tahmin edilmiştir (International Herald Tribune, 16.11.1979: 2). Tankerin 54 kişilik mürettebatından 3'ü kurtarılmış diğerlerinin ölü bedenlerine sonradan ulaşılmıştır. Yunan gemisinin 33 kişilik mürettebatının ise hepsi kurtarılmıştır (The Times, 16.11.1979: 1; İstikbal, 2006: 74). ${ }^{9}$

Yabancı gazeteler içerisinde kaza hakkında en ayrıntılı bilgiyi veren gazetelerden Alman Die Welt kazayı ertesi gün şöyle haber vermiştir;

"Patlamada en az üç kişinin öldüğü ve 43 denizcinin öğleden sonra hâlâ kayıp olduğu haber verilmiştir. Çarpışma Avrupa'yı İstanbul'un Asya yakasından ayıran Boğazın güney ucunda meydana geldi. Londra sigorta şirketi Lloyd's'a göre kayı Rumen denizcilerin hayatta kalma şansı çok az. İstanbul'daki bir polis sözcüsü Die Welt'e Boğaziçi’nin muhtemelen birkaç gün boyunca tüm denizcilik sektörüne kapatılacă̆ını söyledi. Görünüşe göre 'Evriali' Haydarpaşa Limanı'na demirli Rumen tankerine büyük bir kuvvetle çarptı. Görgü tanıklarının ifadelerine göre, çarpışmayı İstanbul genelinde duyulan üç güçlü patlama izledi. Independenta 95 bin ton Libya ham petrolü yüklemişti. Tankerden sizan petrol Boğaz'a döküldü ve ateş yaktı. Büyük ve yanan petrol havuzu Marmara Denizi 'ndeki Moda sahiline doğru sürüklendi. Rumen gemisinin baş mühendisi, bir kahya ve kimliği belirsiz bir mürettebat üyesi kurtarlld ve hastaneye kaldırlld. Mevcut raporlara göre 'Evriali' de bir yangın çıktı. Gemi, sahil güvenlik tarafindan Boğaz'daki Kadıköy limanına çekildi. Türkiye Büyükelçiliği'nden Can Evcan'ın Welt' e verdiği bilgiye göre, 33 kişilik mürettebat güvenli ve iyi durumda olup, denizcilerden bazlları Istanbul Alman Hastanesi'ndedir. Liman yetkililerine göre, kazanın meydana geldiği saat 5.35 'te Boğaziçi hâlâ karanlıktı. Patlamaların gücü, dört milyonluk şehrin Avrupa ve Asya yakasında 10 kilometre yarıçapında on binlerce pencere camını tahrip etti, müze ve kiliselerde değerli sanat eserlerine zarar verdi. Görgü tanıklarının bildirdiğine göre, dünyaca ünlü Topkapı Müzesi'nde vitrinler ve porselen objeler kırıldl. Sultanahmet Camii'nin cam bölmeleri kırlld ve onlar da Ayasofya gibi hemen kapatıldılar. Resmi raporların aksine, görgü tanıkları karada yüzlerce yaralanmadan da söz etti. Sabah nehir kenarındaki sokaklarda bir trafik kaosu vard, Avrupa'dan Asya'ya günlük seyir yapan on binlerce taşıt trafiğe takıldl. Kaza mahallinin birkaç kilometre kuzeyindeki Avrupa Köprüsü, öğleden sonraya terk edilmiş arabalar tarafindan tıkanmıştı. Öğleden sonra İstanbul Valisi Orhan Erbuğ İstanbul sahillerinin sakinlerini 'yaklaşan patlama tehlikesi' konusunda uyardl. Yetkililere göre çarpışma anında hava koşulları 'mükemmel'di ve sis yoktu. Ancak Sovyet Dzanow limanından gelen yük

\footnotetext{
${ }^{9}$ Kaza sırasında Rumen tankerinden denize atlayan gemicileri kurtaran üç gence Cumhurbaşkanı Korutürk adına 1. Ordu ve İstanbul Sıkıyönetim Komutanı Nejdet Oruğ tarafından ödül ve takdirname verilmiştir (Tercüman, 15.12.1979: 1). İndependenta'nın mürettebatından ölen 23 kişinin cesedi, Romanya'nın İstanbul Başkonsolosluğu tarafından görevlendirilen iki uzman tarafından 18'i İstanbul, 2'si Bandırma, 1'i Erdek, 1'i Gebze ve 1'i de Karamürsel sahillerinde bulunmuştur (Tercüman, 7.12.1979: 3).
} 
gemisinin Türk kılavuzu olup olmadığı belli değildi. Boğaziçini geçerken bu zorunludur",

(Die Welt, 16.11.1979: 22). ${ }^{10}$

Çok kuvvetli bir patlamayı 18 Kasım ve 6 Aralık'ta iki patlama daha takip etmiş ve bu da denize daha fazla petrol salınmasıyla sonuçlanmıştır. $6 \mathrm{~km}$.'ye kadar olan binalar zarar görmüştür (http://www.itopf.org/in-action/case-studies/case-study/independenta-boshporus-turkey-1979/;

Milliyet, 7.12.1979: 1; Milliyet, 11.12.1979: 1; Milliyet, 18.11.1979: 1; Tercüman, 7.12.1979: 1). Oluşan sıcaktan dolayı Haydarpaşa Garı'nın vitrayları erimiş (Topakoğlu, 2004: 70; Buhur, 2007: 11), çevredeki binaların camları kırılmış olup bunlara Topkapı Sarayı ve Sultanahmet Camii de dâhildir. Kaza hakkında The Times'da yer alan bilgiler şöyledir;

"3 yaralı mürettebat Moda sahillerinde, patlamanın millerce ötesinde bulunmuştur. 33 kişilik mürettebattyla săg kurtulan Yunan gemisinin kaptanı hafif yaralı ve şoktadır. Karadeniz'den Boğaz'a girerken Türk kllavuz alan Yunan kaptanı, Marmara'da kendi başına yolunu bulabileceğini söyleyerek kilavuzu Tophane limaninda gemiden indirmiştir. Yaklaşlk 1,5 saat sonra, tankerlerin gece Boğaz'dan geçmesi yasak olduğundan demirli bir halde gündüz olmasinı bekleyen ${ }^{l 1}$ Rumen tankerine çarpmış̧ır. Kazanın neden olduğu hemen anlaşılamamıştır, Boğazda sık slk kazaya sebep olan sis, o gün Boğaz'da yoktur. İstanbul Valisi Orhan Erbuğ, İstanbul'un kalpayı kurtulduğunu ifade etmiştir. Romanya Hükümeti'nin ricasl ile Ingiliz uzman kaptan Micheal Garnett yanan tankerin çevreye zarar vermemesi hakkinda tavsiyelerde bulunmak üzere İstanbul'a gelmisstir. Garnett, Londra merkezli deniz kirliliği hakkinda dünyaca otorite kabul edilen 'International Tanker Owners Pollution Federation' un üst düzey teknik uzmantdır." (The Times, 16.11.1979: 7)

Halk, patlamayı ilk başta bir sabotaj sanmıştır. Evriali, çarpışmada burnundan yara almış, gemide çıkan yangın Alemdar-II tarafindan söndürülmüştür (Milliyet, 16.11.1979: 1). Kazanın ardından Haydarpaşa mendireği önünde "kocaman bir ejderha gibi" yatan İndependenta, patlamalarla sarsılarak alevler içinde yanarken Haydarpaşa önlerinde karaya oturmuş, bu nedenle tankerin açık denize çekilmesi yapılamamıştır (Hürriyet, 16.11.1979: 1; Tercüman, 16.11.1979: 1, 13). ${ }^{12}$

Milli Eğitim Bakanlığı; Kadıköy, Moda ve Fenerbahçe'de bazı ilk, ortaokul ve liselerin tatil edildiğini açıklamış, Marmara Belediyeler Birliği tarafından denize kıyısı olan belediyelere şu telgraf gönderilmiştir;

"Halkın uyarllarak kiyllardan uzak tutulmasl, yangina karşı tedbirlerin alinması ve bütün belediye itfaiyelerinin alarma geçirilmesi radyo ve meteoroloji bültenlerinin sürekli izlenmesi, yöre halkının deniz ürünlerini yememesi konusunda uyarlmasl, klyllardaki balıkçıların ve deniz araçları sahiplerinin yangına karşı uyarılması, sahillerde yer alan kamu ve özel sektör kuruluşlarının alarma geçirilerek yangın tedbirlerinin koordineli bir şekilde alarma geçirilmesi gerekmektedir.” (Tercüman, 16.11.1979: 12)

\footnotetext{
10 “Boğaziçi’ni geçerken bu (kılavuz almak) zorunludur." ifadesi doğru değildir, ileride bu konuyla ilgili bilgi verilecektir.

${ }^{11}$ Montrö Boğazlar Sözleşmesi’nin birinci bölümünün 2.-7. maddelerinde ticaret gemilerinin geçiş rejimi düzenlenmiştir. Buna göre barış zamanında ticaret gemileri, bayrağı ve yükü ne olursa olsun gündüz ve gece Boğazlardan geçiş serbestliğinden tam olarak yararlanacaktır (Soysal, 2005: 275). Dolayısıyla haberdeki "tankerlerin gece Boğazdan geçmesi yasak olduğundan demirli bir halde gündüz olmasını bekleyen” ifadesi doğru değildir. Kazayla ilgili Cumhuriyet Senatosunda konuşan Oramiral Hilmi Fırat da; “Karadeniz'e çıkmak üzere İstanbul Boğazı 'nın güney girişinde kılavuz bekleyen Rumen bandıralı 195 tonluk Independanta tankeri" ifadesiyle tankerin orada kılavuz beklediğini ifade etmiştir (Cumhuriyet Senatosu Tutanak Dergisi, 20.11.1979: 97).

${ }^{12}$ Haydarpaşa mendireği ve tanker yangınının göründüğü sahil şeridi bu görüntüye bakmaya gelen aileler ile dolmuştur. İstanbullular mesireye gider gibi yangın seyretmeye gitmişler, herkese korkulu günler yaşatan tanker yangını adeta bir "eğlence" haline gelmiştir (Tercüman, 19.11.1979: 1). İnsanların bu ilgisini firsata çeviren bir vatandaş rıhtıma kurduğu bir dürbünle yanan gemiyi seyrettirerek kendi ifadesine göre 3 günde 5 lira karşılığında 6 bin lira kazanmıştır. Günde ortalama 400 kişinin tankeri seyrettiğini ifade eden girişimci, "keşke yangın daha uzun sürse de daha fazla kazansam" demiştir (Hürriyet, 29.11.1979: 3).
} 
Kazanın ardından ordu ve İstanbul Sıkıyönetim Komutanlığı da bir bildiri yayımlamış ve alınan tedbirler hakkında bilgi vermiştir; 1. Yabancı bandıralı petrol yüklü bir tanker Haydarpaşa açıklarında tehlikeli bir şekilde yanmaktadır. Kız Kulesi ile Moda arasının gerek deniz gerekse sahil kısmı tehlikeli bölgedir. Denizden hiçbir aracın bu bölgeye yaklaşmaması, sahil kesiminde oturan vatandaşların ise müteyakkız bulunmaları iskele ve sahillere ilgisi olmayanların girmemeleri, 2 . Bu bölgedeki şehir hatları deniz ulaşımının durdurulduğu, ilgili makamlarca her türlü güvenlik tedbirinin alındığı sayın İstanbullulara duyurulur (Barış, 16.11.1979: 4). Tankerde yeni patlamalar beklendiğinden Haydarpaşa ve Kadıköy iskelelerinden Karaköy-Kadıköy vapur seferleri yapılamamış, aşırı kalabalıklaşan ve sıklaşan diğer seferler yüzünden vapurlar köprüde hangi iskele boşsa oraya yanaşmış, yolcular böylece hesapta olmayan yerlere çıarılmışlardır (Tercüman, 20.11.1979: 1; Milliyet, 20.11.1979: 1).

\section{Kaza ve Yarattı̆̆ı Çevre Kirliliği}

Yıllar içerisinde Türk Boğazlarında, özellikle İstanbul Boğazı girişinde olmak üzere, deniz ve çevre kirliliğine yol açan birçok ciddi kaza yaşanmıştır. Bu kazalar can kaybına ve yaralanmalara yol açmış, kıyıdaki tarihi yalılara ve kültürel mülkiyete, deniz yaşamı ve sualtı kaynaklarına ciddi ekolojik zararlar vermiş, deniz trafiğini aksatmıştır. Dünyadaki çeşitli tanker kazaları çevre felaketlerine yol açtığı gibi Türk Boğazlarını da potansiyel bir tehlike olarak tehdit etmiş ve sosyal kargaşaya yol açmıştır (Kurumahmut, 2006: 17). Örneğin, Boğaz'daki bu kazadan sonra, Türkiye sahili yanan petrolün tehdidi altında kalmış (Die Welt, 16.11.1979: 1), çarpışmanın olduğu gün Boğaz trafiği durmuş, 80 kadar gemi Karadeniz'den Ege Denizi'ne tek geçiş yolu olan Boğaz girişine yığılmıştır (International Herald Tribune, 16.11.1979: 2).

Yılda 8 bin tanker denizleri dolaşmakta ve pek azı kazaya neden olmaktadır. Fakat tankerlerin karışı̆̆ı kazaların sayısı az da olsa verdikleri zarar büyüktür. Bu kazaya kadar, tanker kazaları sonrası çevre kirlenmesinde rekor "Amoco Cadiz" kazasına aittir. ${ }^{13} 1965$ 'den itibaren tankerlerin tonajında \%284, kaza sonucu denize yayılan kimyasal artıklarda ise \%340 çoğalma olmuştur (Hürriyet, 9.11.1979: 5).

Gemi kazaları dört kategoriye ayrılmaktadır: çarpışma, karaya oturma, yangın ve kıyıya vurma. Bütün bu kazaların hepsinin çevreye farklı farklı zararları dokunmaktadır. Bu kazalar içerisinde en başta gelen kaza çeşidi çarpışmadır. Çarpışma, zayıf görüş ve güçlü akıntılar nedeniyle seyir kabiliyetinin başarısız olması nedeniyle olmaktadır. Çalışmamıza konu olan bu kazada, çıkan yangın sonrası havadaki maksimum parçacık birikimi $1,000 \mathrm{mg} /$ metreküpe erişmiştir, bu insan sağlığı için ayarlanmış makul ölçünün en az dört katından daha fazladır (Öztürk, Poyraz, Özgür, 2006: 120; Küçükyıldız, 2014: 27). Dev tankerlerin neden olduğu kazalar, büyük miktarlarda ham petrol salınmasına neden olabilir ve ağır tanker trafiği bu riski arttırır ki, İstanbul Boğazı gibi dar kanalları olan Boğazlarda durum daha da zordur. Burada petrol yayılmasıyla sonuçlanan ve çevreye ve insan hayatına en çok zararı veren 5 büyük deniz kazası olmuştur; 1979'da İndependenta, 1991'de Rab-Union 18, 1994'de Nassia, 1997'de TPAO ve 1999'da Volgoneft-248. Belirtmek gerekir ki, 1979'daki kaza İstanbul'daki açık ara en büyük deniz kazasıdır. Deniz yüzeyinde ve kıyı şeridinde ağır petrol kirliliği oluşturmuş, 30 bin ton petrol yanmış, 64 bini denize yayılmıştır (Doğan, Burak, 2007: 389; Ünlü, 2018: 103; Öz, Demirel, 2018: 266).

İndependenta kazası, İstanbul'daki en büyük deniz kazası olmasının yanında, şiddetli deniz ve hava kirliliğine yol açan dünyadaki en büyük 20 petrol yayılması kazalarından birisi olup (Ülker,

\footnotetext{
131978 yılında Fransa' da yaşanan Amoco Cadiz tankeri kazasında denize 223 bin ton petrol yayılmıştır (Çiçek, 2018: 382; Jernelöv, 2010: 355).
} 
Baltaoğlu, 2018: 368), ${ }^{14}$ 10. sıradadır (Orakçı, 2006: 58; Birpınar, Talu, Su, Gülbey, 2006: 6) ${ }^{15}$. Çarpışmadan dolayı $5,5 \mathrm{~km}$. çapındaki denizalanı kalın bir katran tabakasıyla kaplanmıştır. Bu bölgede kazadan sonra deniz türlerinin ölüm oranı \%96 olarak tahmin edilmektedir (Usluer, Oğuzülgen, 2018: 7; Doğan, Burak, 2007: 389) ve sadece 9 deniz canlı türü yaşamaya devam edebilmiştir (Erkebay, 2018: 377).

Türkiye Çevre Sorunları Vakfı Genel Sekreteri Engin Ural, Rumen tankerinden denize 48 bin ton ham petrol döküldüğü bilgisini vermiştir. İndependenta kazası, Türkiye'nin karşılaştığı en önemli çevre kirliliği zararını meydana getirmiştir. Tanker patlaması ile aniden ölen balıklar yanında, denize karışan ham petrol balık yavrularını, yuvalarını ve yumurtalarını da etkilemiştir. Vakıf bünyesindeki yaptıkları çalışmada bu konudaki verileri toplayan bilim adamları, 1980-1987 arasındaki 7 yıllık devrede elde edilebilecek balıklardan yoksun kalınması nedeniyle 40 milyar lira zarar olduğunu saptamışlardır (Milliyet, 8.8.1981: 4). ${ }^{16}$ Kaza sonrası denizin kirlenmesi nedeniyle İstanbul'da balık satışı durmuş, İstanbul Balıkçılar Derneği Başkanı Kemal Yarar, İstanbul Valiliği'ne başvurarak hale gelen balıkların çoğunun Karadeniz'de tutulan balıklar olduğundan halkın balık yemesinde bir sakınca olmadığının devletçe duyurulmasını istemiştir. Bunun üzerine İstanbul Valisi Orhan Erbuğ, halkın Marmara'da kazadan uzak yerlerden ve Karadeniz'den tutulan balıkların yemesinde bir sakınca olmadığını duyurmuştur. İstanbul Üniversitesi Kimya Fakültesi Dekanı ve Çevre Sorunları Enstitüsü Müdürü Prof. Dr. Fikret Baykurt'un verdiği bilgilere göre, petrolün yanmasıyla çevreye karbonmonoksit, karbondioksit, hidrokarbonlar ve insan sağlığını olumsuz yönde etkileyen hatta kansere yol açabilen benzpiren ve benzeri kimyasal maddeler yayılmıştır. $\mathrm{Bu}$ nedenle bu gazların yayıldığı bölgelerde, gazın etkisi geçene kadar kapı ve pencerelerin açılmaması, çocukların sokağa çıkarılmaması ve okullarda teneffüs yapılmaması önerilmiştir (Milliyet, 17.11.1979: 9; Hürriyet, 17.11.1979: 1).

Türk Deniz Kuvvetleri tarafından yapılan yangınla mücadele girişimleri başarısız olmuş, Boğaziçi birkaç hafta trafiğe kapatılmıştır. Liman girişinde bir patlama olmasına rağmen Haydarpaşa limanına bir miktar petrol girmiştir (http://www.itopf.org/in-action/case-studies/casestudy/independenta-boshporus-turkey-1979/). Kaza sonrası çıkan yangının söndürülmesi için

\footnotetext{
${ }^{14}$ Tüm dünyada yaşanan başlıca petrol yayılması olayları; 1967'de Torrey Canyon, 1989'da Exxon Valdez, 1999'da Erika, 2002'de Prestige ve 1979'da Independenta (Taşkın, Akçalı, 2018: 244). Torrey Canyon kazası, ilk büyük petrol yayılması vakası olduğu ve bu ilk seferde böylesine geniş petrol yayılması karşısında yeterli deneyim olmadığından alınan önlemler büyük ölçüde doğaçlama olmuştur. Petrolü yakmaya çalışan İngiliz askeri uçakları, enkaz ve yüzeydeki petrolü napalm ile bombalamıştır (Jernelöv, 2010: 355). 1967 yılından sonra petrol yayılması miktarları; Atlantic Empress (1979) 287 bin ton; Abt Summer (1991) 260 bin ton; Castillo De Bellver (1983) 252 bin ton; Amoco Cadiz (1978) 223 bin ton; Haven (1991) 144 bin ton; Odyssey (1988) 132 bin ton; Torrey Canyon (1967) 119 bin ton; Sea Star (1972) 115 bin ton; Irenes Serenade (1980) 100 bin ton; Urquiola (1976) 100 bin ton; Hawaiian Patrior (1977) 95 bin ton ve Independenta (1979) 95 bin ton (Çiçek, 2018: 382; Jernelöv, 2010: 355). 1967-1979 arası dünyanın en büyük tanker kazaları; 18 Mart 1967 Torrey Canyon (İngiltere açıkları), 29,400,000 galon petrol kaybı; 6 Eylül 1967 Stoner tankeri (Wake Island), 6,006,000 galon; 5 Mayıs 1968 Andron tankeri (Bat1 Afrika) 4,914,000 galon; 3 Haziran 1968 World Glory (Güney Afrika), 13,000,000 galon; 5 Kasım 1969 Keo (Massachusetts açıkları) 8,820,000 galon; 12 Mayıs 1976 Urquiola (İspanya) 21,941,000 galon; 14 Ekim 1976 Boehlen (Brest, Fransa) 3,134,000 galon; 15 Aralı 1976 Argo (Massachusetts) 7,700,000 galon; 30 Aralı 1976 Olympic Games (Delaware nehri, ABD) 133,000 galon; 17 Ocak 1977 İrenes Challenger (Midway Adas1) 3,150,000 galon; 24 Şubat 1977 Hawaiian Patriot (Hawaii) 30,000,000 galon; 3 Mart 1977 Borag, (Taiwan açıkları) 3,134,000 galon; 20 Mart 1977 Claude Conwey (Kuzey Carolina açıkları) 536,000 galon; 17 Mart 1978 Amoco Cadiz (Bretanya) 54,600,000 galon (Hürriyet, 16.11.1979: 6).

15 İstanbul Boğazı ve Marmara Denizi’ndeki büyük tanker kazaları şunlardır; 14.12.1960'da World Harmony (Yunan) ve Peter Zoranic (Yugoslavya) arasında Kanlıca'da olan çarpışma ve yangın sonucu 18 bin ton petrol yayılması; 15.9.1964'de Norborn (Norveç) ve Kanlıca'daki Peter Zoranic enkazı arasında sürtünme sonucu yangın ve petrol yayılması; 1.3.1966'da Lutsk (SSCB) ve Kransky Oktiabr (SSCB) arasında Kıkulesi'nde çarpışma ve yangın sonucu 1,850 ton petrol yayılması (Güven, 2006: 140).

${ }^{16}$ Tabi bu bir tahmin olmaktan öte gidemez. Nitekim Gürsoy, çıkardığı yangın ve deniz trafiği için ciddi bir tehdit olan enkazı ile İndependenta'nın Türkiye'ye ve dünyaya toplumsal maliyetinin hiçbir zaman hesaplanamayacağını, sonrasında bile toplumsal maliyet kavramına uzak olan Türkiye'nin o yıllarda böyle bir maliyet hesabı yapmasının mümkün olmadığını ifade etmiştir (Gürsoy, 2004: 116).
} 
İstanbul ve çevre itfaiyelerden yardım istenmiştir. Çaplı söndürme gemisi ile yapılan soğutma çalışmaları patlama ve petrol yayılmasını azaltmıştır (Milliyet, 24.11.1979: 1).

Kazadan bir hafta sonra Marmara Denizi, tankerde kalan ham petrol nedeniyle bir petrol yayılması ile karşı karşıya kalmıştır. İstanbul Üniversitesi'nden uzmanlar, yanan tankerlerden petrol dökülmesini önlemek için denize üç kilometrelik büyük bir yüzer bariyer yerleştirerek tehlikeyi önlemeyi önermişlerdir (Die Welt, 22.11.1979: 24). Nitekim bu öneriler üzerine, İngiltere'den $1 \mathrm{~km}$. uzunluğunda bariyer ve 50 varil solvent getirilmiştir. Ayrıca bu malzemelerin kullanılmasını öğretmek amacıyla 3 İngiliz uzman İstanbul'a gelmiştir (Hürriyet, 24.11.1979: 5). ${ }^{17}$ Ayrıca yangıın esnasında Ulaştırma Bakanlığı tarafından olay yerinin koordinatörü olarak görevlendirilen TOVALOP (Dünya Tanker Donatanları Birliği), Bakanlığın isteği üzerine bariyer göndermiş ve Haydarpaşa-Kadıköy mendirekleri arasına konulan bariyerler tanker parlamalarında alevlerin Kadıköy koyuna sıçramasına engel olmuştur (Milliyet, 12.1.1992: 15).

\section{Kazanın Soruşturulması}

İstanbul Boğazı kılavuzlarından Akın Kaptan'ın verdiği bilgilere göre; bu kazada geminin biri telsiz ile "sol sola geçelim" anlamına gelen "port to port" mesajını vermiş, öbür gemi bunu "sola kır" anlamına gelen "bardly port" olarak anlamış ve gemiler çatışmıştır (Milliyet, 19.4.1987: 11). İndependenta'dan denize atlayıp kurtulan 3 tayfadan birisi olan Mihailesel Sorın kaza anını şöyle anlatmıştır; "Koster üzerimize geliyordu, ikaz ettik. Düdük çaldık, bağırdık ama yararı olmadı. Denize atlayarak yüzmeye başladık, diğer arkadaşlarımız geminin içinde diri diri feryatlar içinde can verdi." (Hürriyet, 16.11.1979: 1; Tercüman, 16.11.1979: 1, 13). Yunan gemisinin kaptan1 Adomopulos da; "Bana göre Rumen gemisi rotadan çıkmıştı. Düdük çalıp yol istedim, ama bu işaretleşme sırasında gemiler çok yaklaşmışı " dese de, yetkililer Rumen gemisinin sancak tarafinın orta kısmında, Yunan gemisinde ise sancak tarafının omurga başında hasar olduğunu söylemişler, "Bu durumda çarpan Yunan gemisidir. Çarpışma ise Yunan gemisinin rotadan çıkması sonucu meydana gelmiştir" yorumunda bulunmuşlardır (Tercüman, 17.11.1979: 12) ${ }^{18}$.

Kazanın soruşturulması için Kadıköy Cumhuriyet Savcı Yardımcısı Necdet Mengüç ve İstanbul Savc1 Yardımcısı Rüştü Savaş görevlendirilmiştir. Yunan şilebinin önce 1. Kaptanı Adamopulos Alekos daha sonra 7 mürettebatı gözaltına alınmıştır (Milliyet, 17.11.1979: 9; Hürriyet, 17.11.1979: 1). ${ }^{19}$ Çetin Altan;

"Yunan şilebinde Türk kılavuz var muydl, yok muydu, kılavuz kaptan görevini bitirdikten sonra mı kaza oldu? Türk kılavuz görevini yapmadı mı? Türk Devleti bu soruların

\footnotetext{
${ }^{17}$ Her iki geminin de iki ayrı İngiliz kulübünde sigortası vardır. Bariyer, solvent ve uzmanların getirilmesi Rumenlerin kendi sigorta şirketlerini harekete geçirmeleriyle olmuştur (Tercüman, 10.12.1979: 4).

${ }^{18}$ Yunanlı kaptanın kusurlu olduğunu belirten bilirkişi heyeti, Deniz Kuvvetleri Komutanlığı'na mensup bir albay ile Yüksek Denizcilik Okulu'nda görevli bir uzun yol kaptanı ve bir makine mühendisidir ( Tercüman, 20.11.1979: 12). Kaza sonrasında olay yerinde incelemeler yapmak üzere İstanbul'a gelen Yunanlı uzmanların hazırladığı raporda, kazanın sorumluluğu Rumen kaptana yüklenmiş, bu kanıya "Boğaz trafiğinin gözönüne alınarak varıldığı" belirtilmiştir (Tercüman, 28.11.1979: 3).

${ }^{19}$ Yunan Hükümeti tanker kazasında suçlu bulunarak tutuklanan iki Yunanlı denizciye hapishanede kötü muamele yapıldığg gerekçesiyle Türk Hükümeti'ni resmen protesto etmiş, denizcilerin kefaletle serbest bırakılmalarını istemiştir. Yunanistan'ın Ankara Büyükelçisi Papulas, Türk Dışişleri Bakanı'nı ziyaret ederek İstanbul'da hapiste bulunan iki kaptanın suçsuz olduklarını, hapiste eziyet gördüklerini bildirerek kefaletle serbest bırakılmalarını istemiştir (Tercüman, 29.11.1979: 1, 12). Bununla yetinmeyen Yunanlılar, iki Yunanlı kaptanın yargılanmasına misilleme olarak Pire limanında 5 Türk denizcisini tutuklamışlardır. Panama bandıralı "Lakista 2" gemisinin Türk kaptanı Metin Caha mürettebatını tamamlamak için Pire limanından 5 Türk denizcisini almak istemiş, Yunanlı polisler kaptandan gemideki Türk denizcileri kovmasını istemiştir. Kaptanın bunu kabul etmemesi üzerine Türk denizcilerin pasaportlarındaki vizelerin sahte olduğunu iddia eden Yunanlı polisler 5 Türk denizcisini gemiden indirip hapsetmişlerdir (Hürriyet, 29.11.1979: 3). Yunanlı denizcilere hapishanede kötü davranıldığı iftiralarına ise Yunanistan'da hükümet yanlısı Katimerini gazetesinde yazar olan Dora İlyopulu-Rogan karşı çıkmıştır. Tanker kazası olduğu sırada Türkiye'de olduğunu ve kendisinin en ufak bir kötü muamele yapılmadığı belirten Rogan, "Yunan kaptanlarının tutuklandıktan sonra hapishanede kötü muamele gördüklerine dair Yunan gazetelerinde çıkan yazıların mübalağalı olduğunu tespit ettiğini” ifade etmiştir (Tercüman, 9.12.1979: 5).
} 
cevabını vermeli ve gereken sorumluluğu almalıdır. Kazadan Yunan şilebi suçluysa, zarar gören herkesin zararını şilebin bağlı olduğu sigorta şirketi tanzim etmelidir. Yok eğer kazadan Türk kılavuzu sorumluysa o zaman Türk Devleti her türlü zararı karşılamalıdır. Yoksa bu Türk Devletinin uluslararası saygınlığını tehlikeye atar" (Milliyet, 19.11.1979: 5)

derken; Ulaştırma Bakanlığı Müsteşar Vekili Çakır, kaza sırasında her iki gemide de kılavuz kaptan bulunmadığını açıklamış ve Yunanlı kaptanın, Türk Ceza Kanunu'nun 333/2 maddesi uyarınca en az beş y1l süreyle hapsinin istendiğini bildirmiştir (Milliyet, 20.11.1979: 1; Bugün, 28.11.1979: 5) ${ }^{20}$

Yunan şilebinin iki sorumlusu 13 Aralık’ta Kadıköy 1. Ağır Ceza Mahkemesi’nde başlayan davanın ilk duruşmasında, "Biz tankere çarpmadık, tanker bize çarptı" demişlerdir. Edinilen bilgilere göre, kazadan üç ay önce kaptan olan Adamopulos 28 yaşında olup ilk kez Boğazdan gemi geçirirken bu kaza olmuştur. Yunan şilebinin kaptanı ve zabiti Lagos Avengelos sorgularında "Biz denizciler kardeşiz. Rumen gemicilerin ölümünden elem duyuyoruz. Çevre kirlenmesi nedeniyle Istanbul halkından da özür dileriz, ama kazada suçumuz yok." demişlerdir. Bu ifadeye rağmen bilirkişi raporuna göre, Yunan kaptan onda dokuz kusurludur (Milliyet, 14.12.1979: 1; Hürriyet, 14.12.1979: 3). Yunan kaptan kazadan sonra tutuklanmış, yargılanarak 20 ay hapis cezası almıştır. Daha sonra tutukluluk süresi göz önünde tutularak 850 dolar ödeyerek serbest kalmıştır (http://www.marinarii.ro/nave-de-istorie.php?id=2\&name=Nava_Independenta).

Patlama sirasında Kadıköy'de 1,800 metrekare, tüm İstanbul'da 5,000 metrekare cam kırılmıştır. Topkapı Müzesi'nde 50 bin liralık, Sultanahmet Cami'inde 20 bin liralık cam kırılmıştır. Kadıköy Kaymakamlığı hasar tespiti için komisyon kurarak patlama sonucu camları kırılanların ve zarar görenlerin başvuru yapmasını istemiştir. Romanya kazayı soruşturmak üzere bir heyeti İstanbul'a göndermeye karar vermiştir (Hürriyet, 17.11.1979: 13).

Türk Uzakyol Gemi Kaptanları Derneği Yönetim Kurulundan Kaptan Refik Akdoğan;

\begin{abstract}
“Ístanbul Limanı Allah'a kalmıştır. Ístanbul Boğazı’ndaki deniz trafik sistemi değişmedikçe, gelişi güzel demirlemelerin önüne geçilmedikçe ve radar sistemi konmadıkça bu kazalar devam eder. Ístanbul limanında bir başıboşluk hâkim. Bugünkü kazada Yunan kosteri 95 bin tonluk koskoca bir tankeri nasıl göremez? Ufak bir ada büyüklüğündeki tankeri görememesinin sebebi bence sisten görüşün bulunmamast. Uluslararası su yolu böyle olur mu? Bu sulardan geçecek tankerin, şilebin önünde mutlaka bir römork olmasl ve radar sistemiyle bu teknelerin seyirlerine devam etmesi lazım." demiştir (Hürriyet, 16.11.1979: 14).
\end{abstract}

Kaza nedeniyle Meclis’teki görüşmelerde konuşan İstanbul Senatörü Vefa Poyraz, dünyada birçok limanlarda ve kritik bölgelerde olan elektronik kumanda ve kılavuzlama sistemleriyle emniyetli bir trafiği sağlamanın, İstanbul Boğazı'nda Türkiye Cumhuriyeti'nin görevi olduğunu ifade etmiştir (Cumhuriyet Senatosu Tutanak Dergisi, 20.11.1979: 100). AP Antalya Milletvekili İhsan Ataöv de, İstanbul ve Çanakkale Boğazlarında 10 bin tondan yukarı gemilerin geçişlerini yeni esaslara bağlayan bir kanun teklifini Meclis Başkanlığı'na vermiştir. Kanun teklifi gerekçesinde, devletlerarası anlaşmalarla Boğazlardan geçişin serbest bırakılmasının özellikle son zamanlarda milli sınırlar içinde milli servete herkesin gelişi güzel zarar vermesi anlamını taşımadığı, özellikle akaryakıt tankerlerinin Boğazlarda meydana getirdiği problemlere karşı zararları önleyici bir sigorta mercii bulunmadığı hususuna yer verilmiştir. Kanun teklifi, İstanbul ve Çanakkale Boğazlarında seyreden 10 bin tondan yukarı gemilerin, denizyollarından sağlayacakları kılavuzla geçmelerini, ayrıca Boğazları ve çevresindeki her türlü milli varlığı, verecekleri hasar mukabili sigorta ettirmeye

\footnotetext{
20 Yunanlı kaptanların tutuklanmasını eleştirenler de olmuştur; "Kaza olunca hemen gemi kaptanlarını yakalayıp hapsetmeyi ve kamuoyunu bu yolla tatmin etmeyi marifet saylyoruz. Bunun hiçbir anlamı yoktur. Sorun birkaç adamı hapse tıkmak değil milyarlara varacak maddi ve manevi zararı teminata ve geçişi tehlikeyi asgariye indirecek kurallara bağlamak ve her devlet gibi koruyucu sigorta sistemine girmektir" (Tercüman, 10.12.1979: 4).
} 
mecbur tutulmalarını ve kılavuz ile sigorta ücretlerinin aracın mensup olduğu devletin parasıyla ödenmesini öngörmektedir (Tercüman, 20.11.1979: 1, 12).

İndependenta kazası, Türk Boğazlarındaki en "trajik" ve "yıkıcı" deniz kazası olmakla birlikte Boğazlardan geçen gemilerin yaratabileceği riskler karşısındaki kamu farkındalığını arttırmış, Boğazlarda kazaları önlemek için gereken tedbirleri almak için yapılan tartışmaları başlatmıştır (Oral, 2006: 23, 28). İstanbul Üniversitesi Deniz Ticaret Hukuku Kürsüsü Öğretim Üyesi Prof. Dr. Raiegen Kender, İstanbul Boğazı'ndaki trafik akışının bütün dünya denizlerindekinin tersine soldan olduğunu söylemiş ve "bu değiştirilmedikçe Boğaz'da sık sık deniz kazaları meydana gelir" demiştir (Tercüman, 19.11.1979: 1). Ve bu tavsiye dikkate alınarak, sağ seyir düzenine bu kazadan sonra karar verilmiş ve 1.7.1982 yılından itibaren uygulanmasına başlanmıştır. İstanbul Boğazı'nda seyir can, mal, çevre ve iş güvenliğini sağlamak üzere 1934-1982 yılları arasında "sol seyir düzeni" takip edilirken, 1982'den sonra "sağ seyir düzeni”" şeklinde sağlanmıştır (Salihoğlu, 2017: 25; Milliyet, 26.9.1985: 9). Başka bir değişiklik, 1979 yılındaki bu kazadan sonra 1987'de başlayan süreçtir. Bu süreç, 1994 yılında deniz yolculuğunun güvenliğini arttırmak, hayatları, deniz ortamını ve mülkleri korumak için çıkarılan yeni bir "Türk Boğazları Tüzüğü" nün yürürlüğe konulmasıyla sonuçlanmıştır (Oral, 2006: 23, 28). ${ }^{21} 1979$ ve 1994 arasında 15 y1l olmakla birlikte, 1994 yılındaki karardan sonra büyük bir kaza ya da yayılma görülmemiştir. Bununla birlikte büyük kazalardan ayrı olarak bütün kazaların sayısında keskin bir düşüş olduğu da görülmektedir (İstikbal, 2006: 74, 75). ${ }^{22}$

\section{Tazminat Meselesi}

Yapılan adli kovuşturma sonucunda bilirkişi, kazada Rumen tankeri kaptanının \%10, Yunan şilebinin süvarisinin \%90 kusurlu olduğunu saptamıştır. Yunan şilebinin süvarisi ve kaptanı aleyhine Kadıköy Ağır Ceza Mahkemesi'nde dava açılmış, şilep süvarisi 3 yıl hapis karşıllı̆̆ para cezasına çarptırılmış, Yunan gemisine de el konulmuştur. Kazadan sonra başta hazine olmak üzere zarar görenler "haksız fiil" isnadı ile tanker sorumluları aleyhine dava açmışlardır. Geminin İngiliz sigorta şirketi "United Kingdom Mutual Steamship" yetkilileri tazminat isteyenlerle temasa geçmiştir. En büyük tazminat davasını 22 milyar 53 milyon 593 bin 985 lira isteyen hazine açmıştır. Hazine, ayrıca 11 milyon 635 bin 074 liralık başka bir dava daha açmıştır. Diğer dava açanlar; İstanbul Belediyesi, Denizcilik Bankası, İPRAŞ, DDY, Ray Sigorta, Halk Sigorta, Deniz Nakliyat Kargo ve şahıslardır (Milliyet, 19.2.1981: 10; Milliyet, 14.11.1980: 6). Olaylarla ilgili olarak açılan 23 davada istenen tazminat miktarı 43,5 milyarı bulmuştur (Milliyet, 10.2.1981: 1). ${ }^{23}$

Rumenler, Türkiye tarafından enkazın kaldırılması için yapılan birçok çağrıyı cevapsız bırakırken Kenan Evren'in Romanya'ya yaptığı gezi, kazanın ve enkaz meselesinin yeniden

\footnotetext{
${ }^{21} 1994$ yılında benzer bir çarpışma Nassia ve Ship Broker arasında olmuş, 20.000 ton petrol yayılmış, 29 mürettebat ölmüştür (Orakçı, 2006: 58).

22 Bahsedilen tüzük, "Boğazlar ve Marmara Bölgesi Deniz Trafik Düzeni Hakkında Tüzük" tür (Resmi Gazete, 1994: 3 47). İstanbul Boğazı'nda 1993 yılına kadar, yılda 25 ile 43 arasında değişen çarpışma olayının meydana gelmesine karşın, 1994 yılı için bu rakam 12'ye kadar düşmüştür. Aynı yılın ilk altı ayında 10 adet çarpışma olayı olmasına karşın, 1.7.1994 tarihinde bu tüzüğün yürürlüğe girmesiyle toplam 2 çarpışma olayı meydana gelmiştir. $\mathrm{Bu}$ da Tüzüğün uygulanmaya başladığı yıl içerisinde dahi kaza oranlarında yaklaşık \% 73'lük bir azalma sağladığını göstermektedir. Tüzüğün ilgili maddeleri gereğince $200 \mathrm{~m}$.'den büyük tankerlerin gündüz geçişi, 250-300 m.'lik tankerlerin geçişleri esnasında Boğaz trafiğinin tek yönlü kapatılması, 300 m.'den büyük tankerlerin geçişleri esnasında trafiğin çift yönlü kapatılması gibi uygulamalar sayesinde çarpışmalar azalmıştır (TBMM Genel Kurul Tutanağı, 1998: 45).

${ }^{23}$ Londra deniz sigorta piyasası İndependenta kazası nedeniyle 10 milyon pounddan fazla tazminat talebinde bulunulmasinı beklemiştir (The Times, 19.11.1979: 15). Bir örnek vermek gerekirse; Fransa Amoco Cadiz kazasından sonra Amerikan mahkemelerinde devam eden uzatmalı davalarda 5 milyon dolardan 10 milyon dolara giden maliyetten söz edilmiştir. Fransa Hükümeti, halk, balıkçılar, yerel yetkililer, otel ve turizm sektöründe çalışanlar, istiridye üreticileri, yosun ve feribot endüstrisi çalışanlarının her biri, Amerikan mahkemelerine 300 milyon dolardan 350 milyon dolara varan tazminat davaları açmışlardır. Fakat incelemelerin bu talep edilen kadar zararın olmadığı şeklinde sonuçlanacağı ve bu meblağın 1/10'unun ödeneceği şeklinde yorumlar yapılmıştır. Fransa Devleti, kazanın olduğu Britanny’ye gelen yabancı turistin \%62, Fransız turistin \%32 oranında azaldığını bildirmiştir (The Times, 21.11.1979: 6).
} 
gündeme gelmesini sağlamıştır (Milliyet, 13.8.1982: 3). Bu ziyaret sırasında Türk ve Rumen Ulaştırma Bakanları arasında tanker enkazının kaldırılması konusu görüşülmüş, Türk tarafı "Enkazın kaldırılmasının mali sorumluluğunun Rumenlere ait olduğunu" belirterek paranın Romanya tarafından ödenmesini talep etmiştir. Fakat Rumenler kazada kendi gemilerinin sorumlu olmadığından hareket ederek, istenen paranın sadece Romanya tarafından ödenemeyeceğini ifade etmişler ve böylece girişim başarısızlıkla sonuçlanmıştır (Milliyet, 7.4.1982: 9).

İlerleyen tarihlerde bu sefer Türk-İngiliz-Rumen heyetleri arasında yapılması planlanan görüşmelerde Türkiye'nin kaza için Romanya'dan 300 milyon dolar isteyeceği bildirilmiştir (Milliyet, 17.1.1985: 9). ${ }^{24}$ Marmara Denizi'ndeki balıkçılar tankerden sızan petrolün denizdeki balık nesline zarar verdiğini ve bundan dolayı büyük kayıp yaşadıklarını belirterek Rumen firma ve sigorta şirketiyle yapılacak bu toplantıya rapor sunmuşlardır (Milliyet, 21.1.1985: 6).

Kazadan sonra kayda değer ekonomik ve ekolojik zarar görülmüş, istavrit, lüfer, palamut balığı gibi kıyıdan uzakta bulunan balıklar bile patlamanın şiddetiyle kıyıya vurmuşlardır. Özellikle balıkçılık alanında çalışanların balık ağları ve tekneleri zarar gördüğünden, 15 balıkçı kooperatifine 291,500 dolar $(350,000,000 \mathrm{TL})$ tazminat ödenmiştir. Bu meblağ balıkçılara 1988 yılındaki mahkeme kararından sonra dağıtılmıştır (Öztürk, Balcıoğlu, 2017: 187, 188). ${ }^{25}$ Fakat sigorta şirketinin balıkçılara verdiği 350 milyonun yarısı devletin, kalanın büyük kısmı da avukatların olmuş, böylece balıkçılara çok az para kalmıştır (Milliyet, 28.2.1987: 3).

Sigorta uzmanlarından Ali Neyzi ise bütün bu tartışmaların dışında kalan ve kimsenin aklına gelmeyen maddi kayıplara ve tazmin edilemeyecek manevi kayıplara dikkat çekmiştir;

"Tanker patlamasında Topkapı Müzesi'nin camları kirılmış, müze kapatılmış. Yağmurlu günlerde dahi en az 3,000 ziyaretçisi var, 20 lira girişsten günde 60 bin lira, 30 günde 1 milyon 200 bin lira. Balıkçılar balık tutamıyorlar, tuttuklarını satamıyorlar, balık yuvaları da tahrip olmuş, nedir zararın tutarı? Bir adam kalp krizinden ölmüss, bir kadın çocuğınu düşürmüs darbenin şiddetinden, korkusundan. Bu vatandaşın ızdırabını ve zararını kim ödeyecek?" (Tercüman, 10.12.1979: 4).

Kaza dolayısıyla yaşanan kayıp ve zararlar neticesinde açılan tazminat davalarında, Türkiye'nin 1969 Brüksel Konvansiyonu'na ${ }^{26}$ üye olmamasının bedelinin ağır olduğu görülmüştür. Kazadan doğan sorumluluklar, Türk Ticaret Kanunu'nun donatan ve donatma iştirakinin sorumluluğu ile ilgili dar çerçeveli maddeleri içinde halledilmeye çalışılmıştır. Fakat bu maddeler de çok eskimiş ve günün ihtiyaçlarına hiçbir surette uymaz bir haldedirler. Mevcut zorluklar ve enkazın

\footnotetext{
${ }^{24}$ Rumen tankerinin sigortacisı İngiliz P.İ. şirketidir (Milliyet, 29.10.1980: 3).

25 Mahkeme kararının tarihi 25.3.1987'dir. Ödemenin 208,198 doları kaza nedeniyle balıkçıların günlerce balık yakalayamamaları nedeniyle uğradıkları "balıkçılık gelir kaybı" için; 83,280 doları balıkçı tekneleri ağlarının kullanılamaz hale gelmesi ve deniz kirliliği için verilmiştir. Bu ödeme için kesin ve adil bir hesaplama yöntemi yoktur. Örneğin 1994 yılındaki başka bir kazada balıkçılara "Macalister Elliott and Partners" şirketi 400 bin dolar tazminat ödemiştir (Öztürk, Balcıoğlu, 2017: 189). Tazminat ödenen balıkçı kooperatifleri şunlardır; 1. Istanbul Fish Producers Association, 2. Rumeli Kavak Fish Producers (FP), 3. Rumeli Feneri FP, 4. Anadolu Kavağı FP, 5. Sarıyer Yeni Mahalle FP, 6. Garipçe FP, 7. Adalar Aquaculture Production and Valorisation Cooperative (APVC), 8. Anadolu APVC, 9. Büyükdere APVC, 10. Kumkapı APVC, 11. Mimarsinan APVC, 12. Pendik APVC, 13. Ortaköy APVC, 14. Silivri APVC, 15. Anadolu Hisar1 APVC (Öztürk, Balcıoğlu, 2017: 188).

${ }^{26} 1967$ 'deki Torrey Canyon kazası, Brüksel Konvansiyonu'nun imzalanmasına neden olmuştur. Konvansiyonda 50 ülke belli sigorta şartlarına uymada birleşmiştir. Buna imza koyan devletlerin gemileri "Blue Certificate" (Mavi Sertifika) denen bu sigortayı göstermeden limanlara girememektedirler. Tekne sigortaları uzmanı Osman Yücesan'a göre, eğer Türkiye kazanın olduğu tarihe kadar anlaşmayı imzalamış olsaydı "Rumen mi kusurlu Yunan mı kusurlu?" gibi ayrıntılarla uğraşmadan sigorta her ikisinin de kusurlu olduğu esasılyla tazminata bağlanabilecekti. Suriye, Lübnan, İsrail, Misır dâhil Akdeniz'de Konvansiyon'a girmeyen ülke yoktur. Üstelik bu konvansiyon yeterli görülmeyip "International Fund" denen mali müessese de 1971'de kurulmuştur. Bu fona üye ülkeler belli ödemelerde bulunurlarken, fon da tazminat ödemektedir. Konvansiyon'a göre donatanın açık kusuru yoksa 16,5 milyon dolarlık otomatik işleyen bir mesuliyet sınırı getirilirken, International Fund da 38 milyonluk ek bir tazminat getirmiştir. Kısaca bu kazada iki gemi olduğuna göre Türkiye, Brüksel Konvansiyonu'nu imzalasaydı, 150 milyon dolarlık bir tazminatı alabilecekti (Tercüman, 10.12.1979: 4).
} 
kaldırılması ise, Deniz Ticaret Hukuku'nun maddeleri ve Limanlar Kanunu'nun sınırlı maddeleri ile halledilmeye çalışılmıştır. Sigorta uzmanı Osman Yücesan, bu tip kazalarda daha çok mağdur olmamak için Türkiye'nin en kısa zamanda 1969 Brüksel Konvansiyonu'na girmesini tavsiye etmiştir. Kazadan sonra herkesin Montrö Boğazlar Sözleşmesi'ne temas ettiğini ve bunun değiştirilmesi gerektiğini öne sürdüğünü belirten Yücesan; bu sözleşme çok taraflı, çok kapsamlı ve içeriği daha çok politik olan bir anlaşma olduğundan, hiçbir surette Boğaz'daki trafiğin zaman ve yerini değiştirmeye, daha iyi kontrol yapılmasına, sigorta mecburiyeti konulmasına mani olmadığı gibi meydana gelecek hasarlarda önleyici tedbirlerin alınmasına hiçbir surette engel olmadığını belirtmiştir. Başta IMCO (The Intergovernmental Maritame Consultative Organization-Uluslararas1 Denizcilik Danışmanlık Örgütü) olmak üzere uluslararası kuruluşların, Türk Deniz Kuvvetleri’nin, Liman İdarelerinin birleşerek mevcut deniz trafiği kurallarını gözden geçirmelerini tavsiye eden Yücesan, gerekli değişikliklerin yapılmasının bütün alakalılarca kabul edileceğini düşünmektedir. ${ }^{27}$ Yücesan'a göre, Türk Hükümeti'nin ve kamuoyunun üzerine düşen görevler şöyle siralanabilir; hukuki ve fiziki önleyici tedbirleri almak, mümkünse Boğaz'dan petrol taşınmasına mani olacak projeler geliştirmek, deniz kirliliğini önleyecek tazminat alınmasını kolaylaştıracak kanuni yolları hazırlamak, gerekli konvansiyonları takip ederek zamanında buralara iltihak etmek (Yücesan, 1980: 7).

\section{Montrö Boğazlar Sözleşmesi}

Karadeniz'i Marmara Denizi ile Ege Denizi'ne bağlayan ve ayrıca Avrupa ve Asya kıtalarını birbirinden ayıran İstanbul Boğazı, Karadeniz ile Akdeniz'i birbirine bağlayan en önemli petrol taşımacılı̆̆ 1 yollarından biridir. Ayrıca Malakka Boğazı gibi yoğun ve tehlikeli bir deniz trafiğine sahiptir. Sadece dünyanın en dar boğazlarına değil, aynı zamanda ondan fazla keskin dönüşlere sahip olmasıyla dikkat çekmektedir (Usluer, Alkan, 2016: 18).

Türk boğazlarının kendine has özelliklerini Mehmet Gönlübol şöyle sıralamıştır;

1. Montrö Boğazlar Sözleşmesi’ne göre "Boğazlar” genel deyimi içine İstanbul Boğazı, Marmara Denizi ve Çanakkale Boğazı girdiğinden Türk Boğazları dünyada en uzun geçiş yolunu oluşturmaktadır.

2. Türk Boğazlarının üstünde birçok yerleşim bölgeleri ve nüfusu beş milyona varan büyük bir kent bulunmaktadır. çok dardır.

3.Türk Boğazları, özellikle İstanbul Boğazı öteki uluslararası boğazlarla karşılaştırıldığında

4. Başka uluslararası boğazlardan farklı olarak Türk Boğazları belli limanlara gidebilmek için alternatifi bulunmayan bir deniz geçididir.

5. Karasuları içinde hangi genişliği alırsak alalım Türk Boğazları tümüyle Türk ülkesinin deniz sınırları içinde kalmaktadır.

6. Türkiye'de tutulan balığın dörtte birine yakın bir kısmının Boğazlar bölgesinde elde edilmesi, bu bölgede ekolojinin korunmasını ekonomik bakımdan da zorunlu kılmaktadır (Hürriyet, 23.11.1979: 6).

Deniz kazaları bakımından dünyada ilk sıralarda yer alan İstanbul Boğazı'nda kazaların önlenmesi için yetkili bütün kuruluşların bir araya gelip çalışması ve hükümetin de ciddi önlemler alması İndependenta kazasından sonra uzmanlarca istenmiştir. Bu önlemlerin başında "kılavuz

27 Kazadan sonra, İstanbul Boğazı haftalarca kapalı kalmıştır (http://www.itopf.org/in-action/case-studies/casestudy/independenta-boshporus-turkey-1979/; Birpınar, Talu, Su, Gülbey, 2006: 6). Böyle bir zararı diğer alakadarların da istemeyeceği kesindir. 
kaptan"28 alma gelmektedir. Bu da kamuoyunda ve gazetelerde Montrö Boğazlar Sözleşmesi’nin gündeme gelmesine ve değişen şartlar nedeniyle bazı maddelerinin Türkiye lehine değiştirilmesinin önerilmesine yol açmıştır.

Bundan önce yaşanan kazalardan sonra gereken önlemlerin alınmadığını belirten Hürriyet Gazetesi yazarı Çetin Emeç' in bir önerisi vardır; "Kavruk Independenta 'yı alalım fakat sökmeyelim. Yangın söner sönmez o haliyle Marmara'nın göbeğine demirleyelim. Yüzen bir ibret anıtı halinde. Önünden gele geçe kll payı farkla ve Tanrı'nın lütfuyla pek ucuz atlattı̆̆ımız bir facianın anısını hep canlı tutalım." (Hürriyet, 19.11.1979: 5). Tabi bu öneri gereken somut adımların atılması ve kazaların önlenmesi için gerekenlerin yapılmasından sonra anlam kazanacaktır.

Boğazdaki bu facianın İstanbul'u, halkı ve milli serveti, trafiği ve nizamı hiçe sayan ihmal ve saygısızlık yüzünden olduğunu yazan Tercüman gazetesinden Ahmet Kabaklı; dünyanın en mühim ve stratejik milletlerarası su yollarından olan İstanbul Boğazı'nın "Sirkeci trafiğinden beter hâle" getirilmesinden şikâyetçidir. Nerdeyse bütün dünya gemilerinin destursuz girip çıktıkları bu daracık mavi yolda hiçbir trafik kaidesi, hiçbir arama tarama, hiçbir mecburiyet olmaması, isteyen gemi kılavuz alırken istemeyenin almaması, kazanın en büyük nedenidir (Tercüman, 16.11.1979: 2). Bu yüzden Montrö'nün 2. maddesi Türkiye tarafindan derhal kaldırılarak, Çanakkale veya İstanbul Boğazı'ndan girecek bütün gemilere Türk karasularından çıkıncaya kadar kılavuz almak mecburiyeti konulmalı, kılavuz ücreti arttırılmalı ve geçen yabancı gemilerin yükleri kontrol edilerek silah sevkine ve kaçakçılığa engel olunmalıdır. Boğaz kıyılarında büyük gemiler demirletilmemeli, tankerler tenha zamanlarda sokulmalı, yerli tekne, mavna ve çatanaların seyrine çeki düzen verilmelidir (Tercüman, 20.11.1979: 2).

Tercüman Gazetesi’nden Ergun Göze de, Kabaklı gibi geçişin fazla serbest olmasından şikâyetçidir;

"Milletlerarası geçittir diye her önüne gelen dingonun ahırı gibi kullanabilir mi Boğazlarımızı? Bunun tedbiri yok mu? Gece geçmeseler olmaz mı? Yüzbinlerce ton petrol geçiren tanker Türkiye'ye bu geçiş için ne ödemektedir? Ruslar gözümüzün önünde alay ede ede silah geçirirler. Tankerler vizır vizır. Kimse İstanbul'un maruz bulunduğu tehlikenin farkinda değil. Sahipsiz mi bu şehir, bu vatan, bu millet bu kadar?"

Göze'ye göre de, bu kazayla birlikte Türkiye'ye uluslararası platformda bazı teklifler ileri sürmesi için bir büyük firsat ve imkân daha çıkmıştır (Tercüman, 17.11.1979: 6). Çetin Altan ise, "Böyle iki üç kaza daha olursa Montreux Anlaşması yeniden uluslararası gündeme girer." yorumunda bulunarak hemen değil ama Türkiye kendisi talep etmezse uzun vadede Montrö'nün tartışmaya açılabileceğini yazmıştır (Milliyet, 19.11.1979: 5).

Boğazlardaki deniz trafiğini düzenleyen Montrö Boğazlar Sözleşmesi, Türkiye ve Karadeniz kıyıdaşı olan üç devlet olan Sovyetler Birliği, Bulgaristan ve Romanya ${ }^{29}$ ile Fransa, İngiltere, Japonya, Yunanistan ve Yugoslavya arasında 20 Temmuz 1936'da imzalanmıştır. Uluslararas1 gelişmelerin ve Türkiye'nin diğer devletlerle belli bir evredeki barışçıl ilişkilerinin böyle bir anlaşmanın yapılmasının yolunu açtı̆̆ 1 söylenebilir (Soysal, 2005: 275). Anlaşmaya taraf devletlerin ya zamanın en güçlü devletleri ya da Türk Boğazlarını en çok kullanan veya onlarla en ilgili devletler olduğu görülmektedir. Zamanla tüm devletlerin kabul edilen bu kurallara uymalarıyla da Montrö Boğazlar Sözleşmesi'nin maddeleri genel bir rejime dönüşmüştür. Bu kaza, o zamana kadar bu bölgede olan kazaların en büyüğü ve en tehlikelisidir. Montrö'den sonra deniz trafiğginin yıldan yıla

\footnotetext{
${ }^{28}$ Kazanın olduğu yıl Boğaz'dan yılda 20 bin gemi geçmiş, bunların ancak \%60'1 kılavuz kaptan almıştır (Hürriyet, 23.11.1979: 6).

${ }^{29}$ Montrö Boğazlar Sözleşmesi için görüşmeler yapılırken Romanya Dışişleri Bakanı Nicolae Titulescu, Lozan'daki konuların Türkiye'nin avantajına olacak biçimde düzenlenmesini istemiş, aynı zamanda "Boğazlar Türkiye'nin kalbidir ama Romanya'nın da akciğeridir" demiştir (Ciachir, 2002: 658).
} 
gözle görülebilir bir biçimde hızla yoğunlaşması, ${ }^{30}$ bu tür hatta daha tehlikeli kazaların meydana gelmesi olasılığını giderek arttırmıştır. Anlaşmanın Türkiye'nin Boğazlar üzerindeki hak ve yetkilerini açıklayan maddelerinin en önemlileri 2. ve 3. maddelerdir. Boğazlardan transit olarak geçmekte olan yabancı ticaret gemilerinden sağlık denetimi, fener ve şamandıra ve kurtarma hizmetleri için alınabilecek olan vergi ve harçların tutarını altın-frank esasına göre asgari düzeyde saptayan hükümlere göre, bu gemiler için "Kılavuz ve yedekçilik (römorkörcülük) hizmetleri isteğe bağlı" kılınmıştır. Gönlübol'a göre, imzalandığı dönemin koşullarına göre hazırlanmış olan bu sözleşme, sonrasında gereksinimleri karşılamaktan çok uzak kalmıştır. ${ }^{31}$ Sözleşmeden sonra, Türk Boğazlarından geçen yabancı gemilerin sayısında, büyüklüğünde, taşıdıkları yüklerin niteliğinde ve yapılarında çok önemli değişmeler meydana gelmiştir. Bir zamanlar Türk Boğazlarından arada sırada yabancı gemi geçerken kazanın olduğu dönemde iki yöne giden gemiler neredeyse zincirleme bir görüntü almıştır. Sözleşmenin hazırlandığı yıllarda en büyük ticaret gemileri 10-15 bin ton civarında iken, yaklaşık yarım yüzyıl sonra 300-400 bin tonluk tankerler yapılmaya başlanmıştır. Bu tankerlerin geçişinin sağlıklı yapılabilmesi ve Türkiye'nin ve Türk halkının olası tehlikelerden korunması ile ilgili kurallar özellikle tekrar gözden geçirilmelidir. Montrö Boğazlar Sözleşmesi'nin 29. maddesi özel bir konferans toplayarak ya da diplomatik yollardan gerekli çoğunluğun sağlanması halinde sözleşme hükümlerinin değiştirilebileceğini öngörmektedir. Gönlübol'a göre Türkiye bu maddeye dayanarak, Birleşmiş Milletler'in toplantılarını hâlen sürdürdüğü Deniz Hukuku Konferansı'nda yapılan çalışmalardan ve IMCO'nun önerilerinden faydalanarak Türkiye'yi olası tehlikelerden koruyacak bazı değişiklikler yapılmasına çalışmalıdır (Hürriyet, 23.11.1979: 6).

Belirtildiği gibi, kaza sırasında gemilerde kılavuz kaptanların bulunmadığı anlaşılıyor. Beş milyon nüfuslu bir kentin caddesi niteliğinde olan Boğazlardan geçecek gemiler hakkında önlem alınması zorunludur ve Ahmet Şükrü Esmer'e göre bu önlemlerin başlıcası kılavuz almaktır. Montrö kılavuz almayı zorunlu kılmadığından ve kılavuz almak mali külfetler doğuracağ için bir çok gemi kılavuz almamıştır. Montrö Boğazlar Sözleşmesi Türkiye'nin güvenliğini askeri açıdan güvence altına almış, savaş gemilerinin geçit koşulları düzenlenmiş fakat sivil taşımacılıktan doğabilecek tehlikeler dikkate alınmamıştır. Anlaşmanın yapılmasından sonraki süreçte, Boğaz'dan geçen gemilerin sayısının artması ve tonajlarının yükselmesi de tehlikeyi arttırmıştır. Esmer'e göre; " $B u$ gelişmelerin ışı̆̆ı altında ve hele Haydarpaş̧a felaketi deneyiminden sonra Montrö Anlaşması'nın Boğaz'dan geçecek gemileri kılavuz almaya zorlayacak biçimde değiştirilmesi gereği belirmiştir. Türkiye anlaşmayı imzalayan devletleri sadece bu maddenin değiştirilmesi için toplantıya çağırmalıdır." (Barış, 30.11.1979: 3).

Cumhuriyet Senatosu'nda “Boğazlardaki deniz trafiğinin günün ihtiyaçlartna cevap verecek şekilde yeniden düzenlenmesi ve bu arada uluslararası platformda gereken desteğ $\mathrm{i}$ sağlayarak Montreux Sözleşmesinin bu konu ile ilgili maddesine değişiklik getirilmesi zamanı gelmiş hatta geçmiştir.” diyen Oramiral Hilmi Fırat önerilerini şöyle sıralamıştır; İstanbul ve Çanakkale liman tüzüklerinde gerekli değişiklik yapılarak transit halinde bulunan gemiler için yeni bir trafik düzeni getirilmesi, büyük tonajlı ve özellikle yanıcı ve patlayıcı madde taşıyan gemilerin gece ve fena görüş

\footnotetext{
30 Örneğin 1938 yılında İstanbul Boğazı'ndan 4,500 gemi geçerken, 2005 yılında bu sayı 54,794'e yükselmiş ve bunların 10,027'si riskli kargo taşımıştır (Kurumahmut, 2006: 17).

${ }^{31}$ Türkiye Cumhuriyeti'nin Lozan Anlaşması'ndan sonra, Boğazlar rejiminin değiştirilmesi için başvurmasında ana amacı, bölgenin "askersizleştirilmesi" kararını ve Lozan Anlaşması'yla bölgede kurulan milletlerarası rejimi değiştirmektir, ki ikisi de değiştirilerek istenilenler elde edilmiştir (Ekşi, 2017: 128; Rozakis, Stagos, 1987: 115) Ayrıca anlaşma maddelerinin değiştirilmesi yolu, zaten 28. ve 29. maddelerle sağlanmıştır; anlaşmanın 28. maddesine göre anlaşma yürürlüğe giriş tarihinden itibaren yirmi yıl geçerli olacaktır. Bu yirmi yıllık sürenin bitmesinden iki yıl önce, taraflardan hiçbiri anlaşmayı sona erdirme için görüşme istemezse, anlaşma bir sona erdirme görüşmesi talebinden başlayarak, iki yıl geçinceye kadar yürürlükte kalacaktır. 29. maddeye göre, anlaşma yürürlüğe girdiği andan her beş yıllık dönemin sona ermesinde, taraflardan her biri, bu anlaşmanın bir ya da birkaç hükmünün değiştirilmesini önerme girişiminde bulunabilecektir (Rozakis, Stagos, 1987: 122). Anlaşma özellikle hem Türkiye hem de Karadeniz'e komşu devletlerin lehine ve iyiliğine olmuş, Türkiye'yi Boğaz geçişlerinde ve Karadeniz'deki savaş gemilerinin mevcudiyeti üzerinde belirleyici bir role kavuşturmuştur (Rozakis, Stagos, 1987: 135).
} 
şartları altında Boğazlara girmesinin yasaklanması, trafiğin etkili bir biçimde kontrolü için navigasyon kontrol ve kılavuz istasyonlarının tesisiyle boğazlardaki seyir yardımcılarının daha yetenekli bir hale getirilmesi. Ayrica kontrol istasyonlarıyla seyir halindeki gemiler arasında haberleşme sağlanmalı ve mutlak bir trafik disiplini kurulmalıdır. Kazalardan sonra meydana gelebilecek deniz yangınları ile etkili bir biçimde mücadele etmek üzere yeterli bir yangın savunma teşkilatı kurulmalıdır (Cumhuriyet Senatosu Tutanak Dergisi, , 20.11.1979: 98, 99).

İstanbul Boğazı'nda bu dönemde kazaların artmasının nedenlerinden en önemlisi hiç şüphesiz deniz trafiğinin gittikçe yoğunlaşmasıdır. Dolayısıyla alınması istenen önlemler arasında tankerlerin gündüz saatlerinde Boğazlardan geçmeleri, kılavuz alma zorunluluğu getirilmesi, aynı anda tek bir tankerin geçmesine izin verilmesi ve hatta bir tankerin geçişi sırasında diğer ticari gemilerin beklemesi gibi düzenlemeler sayılmıştır. Ancak bu önlemlerin Türkiye tarafından tek yanlı alınabilmesi ve uygulamaya konulabilmesi mümkün gözükmediğinden, Montrö Boğazlar Sözleşmesi'nin 20 yıllık bir süre için yapıldığ 1 ve bu sürenin bitiminde de taraflarca iptal edilmediği için halen geçerliliğini sürdürdüğü hatırlatılmıştır. Diğer yandan bu sözleşme her beş yılda bir, üç ay öncesinde ilgili taraflara bildirmek koşuluyla bazı maddelerin değiştirilmesi istenebileceğinden Türkiye'nin de bunu yapması dönemin gazetelerinde önerilmiştir (Bugün, 4.12.1979: 2).

Türkiye Dışişleri Bakanlığı yetkilileri, zorunlu kılavuzluk önerisini kabul etmekle birlikte düzenlenecek bir konferansta atom denizaltılarının ve nükleer donanımlı gemilerin Boğazlardan geçişleri gibi hassas konuların gündeme gelmesi ihtimaline karşı çok iyi hazırlık yapılması ve konferans için uygun ortam ve zamanın seçilmesi gerektiğini savunmuşlardır (Barış, 17.11.1979: 4).

Türkiye Dışişleri Bakanlığ1 yetkilileri gibi, konunun Montrö Boğazlar Sözleşmesi'nin dışında da çözülebileceğini ifade edenler olmuştur. Örneğin, belirli kalem mallar taşıan belirli tonajdaki gemiler için kılavuz kaptan zorunluğu konulması ve kılavuzluk kurumunun parasız bir hizmete dönüştürülmesi önerilmiştir. Bu değişikliğin, Montrö Boğazlar Sözleşmesi'ni değiştirmeden Karadeniz'e kıyısı olan ülkelerden başlayarak, ikili anlaşmalarla sigorta şirketlerinin dikkatleri ve ilgileri çeşitli yollardan çekilerek yapılması düşünülmüştür (Bugün, 17.11.1979: 1). İhsan Sabri Çağlayangil de bu şekilde düşünenler arasındadır. Ona göre, Boğazlarda geçiş yolları düzenlenmeli ve gemilerin geçişini kolaylaştıran sinyalizasyon örgütü kurulmalıdır fakat bu konuda yeni bir konferansa ihtiyaç yoktur (Tercüman, 17.11.1979: 8).

Yüksek Denizcilik Öğretim Üyesi, Uluslararası Navigasyon Kongreleri Sürekli Birliği Üyesi Yüksek Mühendis Melih Köknel; uluslararası sözleşmelere bağlı kalınarak coğrafi yöreye ve hava koşullarına en uygun düşecek navigasyon kontrol ve ikaz sistemi kurulduğunda ve uluslararası kurallara göre sağ trafik düzeni saptandığında, kritik yerler şamandıralarla işaretlendiğinde, deniz trafiği yakından ve ciddi biçimde izlendiğinde kazaların büyük ölçüde önüne geçileceğini düşünmektedir. Ayrıca konulacak kurallara uymayan gemilere de yüksek para cezaları uygulanması gerekmektedir. Köknel'e göre; Montrö Boğazlar Sözleşmesi’nin 2. maddesindeki “kı1lavuz ve römorkör almak ihtiyarîdir" maddesi de alınacak önlemleri bağlamaz. Türkiye belli tonajdan sonra gemilere kılavuz almayı, römork ve deniz itfaiyesi eşliğinde Boğaz'dan geçmeyi zorunlu kılabilir (Hürriyet, 23.11.1979: 6)

Yüksek Denizcilik Okulu Mezunları Derneği Başkanı Baş Kılavuz Kaptan Kamil Atay, kazaları en aza indirmek için başvurulacak en önemli müessesenin kılavuzluk olduğunu söylemiş, "Bir kaza olduğunda ilk soru gemide kılavuz kaptan var mıydl şeklindedir fakat Boğaz'da kılavuz almak mecburiyeti yoksa birçok gemi de kllavuzsuz seyrediyorsa tehlike büyük bir yüzde ile devam ediyor demektir" demiştir. Atay, Boğazlardan geçişi düzenleyen anlaşmanın günün şartlarının gerisinde kaldığını belirtmiş, anlaşma hükümlerinin yeniden gözden geçirilmesi gerektiğine işaret etmiştir (Tercüman, 28.11.1979: 3).

Boğazlardan geçişte kılavuz alma mecburiyeti koymanın bir tedbir olmakla birlikte meseleyi tamamen halletmeyeceğini düşünen Ulvi Yenal ise, kılavuzun da insan olduğuna ve hata 
yapabileceğine dikkat çekmiştir. ${ }^{32}$ Ona göre alınması gereken tedbirler şunlardır; yolcu ve yük gemilerinin limana giriş-çıkış veya Boğaz'dan geçişlerinin emniyet altında olması için gerekli tedbirleri almak ve disiplini sağlamak, tankerleri limana sokmamak ve Boğaz'dan geçirmemek (Tercüman, 27.11.1979: 2).

Görüldüğü üzere, konuyla ilgili yorum yapan herkes, Montrö Boğazlar Sözleşmesi’nin imzalandığ1 dönemdeki şartlarla İndependenta kazasının olduğu 1979 yılındaki şartların aynı olmadığını kabul etmektedir. Her şeyden önce İstanbul şehrinin Montrö imzalandığında 1 milyon olan nüfusu 1979 yılında altı milyona yaklaşmıştır (Tercüman, 27.11.1979:2). Değişen şartları, deniz sigorta uzmanı ve Türk Gemi Kaptanları Cemiyeti eski Başkanı Kaptan Nejat İncediken şöyle suralamıştır;

1. Anlaşmanın yapıldığı tarihlerde Boğazdan geçiş yapan gemilerin tonaj1 2/3,000 DWT idi. 1979 y1lına gelindiğinde ise bu 100 bin ve daha üst tonajlara ulaşmıştır.

2. Gemilerde kömür ve yelken yerini dizel motoru ve türbine bırakmıştır.

Geçiş şartlarındaki bu değişikler nedeniyle sorunun Montrö Boğazlar Sözleşmesi içinde çözülemeyeceğini ifade eden İncediken, bütün dünyada geçiş şartlarını tesis eden IMCO adlı kuruluşa başvurulması gerektiğini düşünmektedir. İncediken alınması gereken hukuki ve teknik tedbirleri sıraladıktan sonra, bu tedbirlerin Karadeniz'e limanı bulunan ülkelerden birer üye ve Türk yetkililerinin bir araya gelerek bir raporla IMCO'ya başvurup yeniden tertiplenmesini istemesiyle çözülebileceğini yazmıştır (Tercüman, 26.11.1979: 2).

Burada Birleşmiş Milletler Denizcilik Topluluğu'nun, uluslararası 97 delegenin katılımıyla, Kasım ayının başında iki hafta süren ve Londra'da düzenlenen bir organizasyonda okyanuslardaki gemilerin güvenliğini geliştirmek üzere toplanmasından bahsetmek yerinde olacaktır. Bu toplantı mevcutlara yeni kurallar ve düzenlemeler getirmeyecek, devletlerin mevcut kurallara uymalarını sağlamaya çalışacaktır. Son toplantıdan sonra IMCO Genel Sekreteri C. P. Srivastava, bu girişimin güvenlik ve çevre kirliliği ve gemicilerin eğitilmesi, denetlemenin arttırılması ve gemilerin muhafazası konularında daha kesin kuralların konulmasına sebep olacağını ifade etmiştir. Srivastava, toplantıların iyi geçtiğini fakat bazı devletlerin kararları uygulamadığını belirtmiştir. Ayrıca Srivastava, IMCO'nun devletlere uygulama konusunda yardımcı olmak istediklerini, fakat kendilerinin uygulamayıp sadece devletlere bu konuda yol gösterebileceklerini ifade etmiştir. Kararların takibine konsantre olmak için iki yıl boyunca herhangi bir toplantı ve kongre yapmama kararı alınmıştır. Gemi kazalarının \%80'i insan hatasından kaynaklandığı için, devletler ve gemi sahiplerinin işleyiş ve gemiye personel alma uygulamalarını geliştirmeleri kazaların azalmasını sağlayacaktır. IMCO çeşitli devletlere ve daha çok gelişmekte olan devletlere yüksek standartlarda Denizcilik Yüksekokulları kurmaları ve mevcutları modernize etmeleri için yardım etmektedir (The Times, 17.11.1979: 4; The Times, 17.11.1979: 21). Uluslararası bir toplantıda gemi kazalarının \%80’inin insan hatasından kaynaklandığının ifade edilmesi ve böyle bir girişimin bu döneme denk gelmesi, tüm dünyada deniz kazalarının acilen önlem alınmasını gerektirecek şekilde algılandığını gösterdiği için önemlidir.

\footnotetext{
${ }^{32}$ Deniz kazalarında kabul edilen insan hatası, IMCO Genel Sekreteri C. P. Srivastava'nın verdiği bilgilere göre \%80 oranındadır (The Times, 17.11.1979: 4; The Times, 17.11.1979: 21) Deniz kazalarındaki insan hatası National Academy of Sciences'a bağlı bir komisyon tarafından yapılan bir araştırmaya göre şu başlıklarda toplanmıştır; dikkatsizlik, kaptan ve kılavuz kaptan arasında anlaşmazlık, kaptan köşkünün düzensizliği, işletmenin kötü oluşu, bedeni yetersizlik, göz bozukluğu, şiddetli yorgunluk, fazla alkol kullanma, personelin sık sık değişmesi, hesaplanan risk oranının yüksekliği, fenerlerin ve işaretlerin yetersizliği, radarın kötü kullanılması, akustik (ses) işaretlerinin şüpheye mahal verecek şekilde kullanılması, navigasyon kurallarının yetersizliği (Tercüman, 21.12.1979: 2).
} 


\section{Enkazın Kaldırılması}

Kazanın kendisi kadar sonrasında denize gömülen İndepenta'nın enkazının kaldırılması da üzücü ve yıpratıcı bir süreç olmuştur.

Denizcilik Bankası, enkazın sökümünü üstlenecek firmanın belirlenmesi için 9 kişilik bir heyet belirlemiştir. Teklif verenler arasında bir Hollanda firması ile dörtlü bir Türk firması yer almış, ayrıca "Sezen Sokullu" isimli Türk firması Hollandalı "Wijsmüller" şirketiyle ortak şekilde 19 milyon dolarlık bir teklif vermiştir. Rumenler tankerin hurdasının 25 bin ton olduğunu söylerken, Japon bir firma 24 bin ton, Türk hurdacıları 27 bin 500 ton olduğunu düşünmüştür (Milliyet, 3.3.1981: 6).

İndependenta'nın çıkarılması için ciddi şekilde harekete geçilmesi 1981 yılının Ağustos ayını bulmuştur. Yabancı şirketler, söküm için açılan uluslararası ihalelerde döviz olarak 3,5 milyar istemişlerdir. Yurt dışına döviz çıkmaması amacıyla Deniz Kuvvetleri Komutanlığı sökümde kendi elemanlarını çalıştırarak enkazı kaldırmak istemiştir (Milliyet, 13.8.1982: 3; Milliyet, 15.8.1981: 8).

Sonuç olarak enkazın kaldırılması için Deniz Kuvvetleri Komutanlığı Denizcilik Bankası ihaleyi almış, bir Japon şirketi de teknik müşavir olarak görevlendirilmiştir. 17 milyon dolara işi üstlenen Komutanlığın işi bir senede tamamlanması planlanmıştır. Önce tanker çevresini şamandırayla çevirecek olan teknik ekip, çalışma alanına getirilen dev vinçlerle günde 20-25 kişiden oluşan işçilerin çalışmasıyla enkazı 3 parçaya ayırarak Tuzla'ya götürmeyi planlamıştır. Bu kadar zaman sonra tankerde hâlâ 500 tonluk katı yakıt olduğu belirtilmiştir (Milliyet, 15.8.1981: 8).

Fakat işler planlandığ 1 gibi gitmemiş, Deniz Kuvvetleri Komutanlığ 1 yardımcı firmayla anlaşmasını feshetmiştir. Söküm işini taşeron firma olarak üstlenen Sezen Sokullu şirketi, kendilerine tanınan 300 iş gününde enkazın 1/3'ünü çıkarmış fakat zarar ettikleri gerekçesiyle mahkemeye başvuracaklarını ilan etmiştir. Komutanlıkla 885 milyon liraya anlaşan şirket hızlı enflasyon yüzünden zarar ettiği gerekçesiyle anlaşmayı feshetmiştir. Firma, anlaşmayı imzaladıklarında 147 lira olan doların 500 lira olduğunu ifade ederken, Deniz Kuvvetleri Komutanlığı'nın ana vinci 8 ay geç teslim ettiğini ${ }^{33}$ ve anlaşmaya göre verilmesi gereken bazı araçlarla, ithal edilmesi beklenen elektrodların getirilmediğini iddia etmiştir. Devlet hazinesinden o ana kadar 2 milyar lirayı aşkın para harcanmış, Rumenlerden herhangi bir yardım da alınamamıştır. 1985 yılına gelindiğinde enkazın ancak \%35'i sökülebilmiştir (Milliyet, 22.3.1985: 9).

Tankerin sökümüne başlandığı sırada şehir hatlarına ait "Hürriyet" isimli arabalı vapur akşam 22.00'de Haydarpaşa açıklarında bulunan İndependenta'nın sular altındaki enkazı ile çarpışarak karaya oturmuştur. Yakıt almaya giderken tankere bindiren vapurda yolcu olmaması sonucu can kaybı yaşanmamış, sadece hasar oluşmuştur. Kaza tankerin etrafina konan fenerlerin sönmesi yüzünden yaşanmıştır (Milliyet, 21.4.1983: 1; Kutluk, 2003: 306). ${ }^{34}$

1987 y1lına gelindiğinde, bu iş için anlaşılan dört şirketten sonuncusu olan Sezen Sokullu firması enkazın 6 bin tonluk kısmını çıkararak Tuzla'ya taşımış, sözleşme feshedildikten sonra Gemi Söküm ve Ticaret A.Ş. tarafından kalan parçaları da sualtında balıkadamlara parçalatılıp enkazın baş tarafı yüzdürülerek Tuzla'ya çekilmiştir (Milliyet, 11.4.1987: 3).

Sonuç olarak, birçok ihale ve firma değişmesi, karşılıklı zarar etme ve ihmal suçlamaları yaşanmış, İstanbul şehri ve Marmara Denizi bu kazadan ancak 7 yıl sonra enkazdan kurtulabilmiştir diyecekken, bu sefer 23 yıl sonraki bir İSKİ kazısı sırasında tesadüfen İndependenta'nın güvertesi

\footnotetext{
3330 bin ton ağırlığında ve 12 katlı bir apartman yüksekliğinde, 302 metre boyunda olan vinç ABD’den 1983 yılının Eylül ayında getirtilmiştir (Milliyet, 9.9.1983: 3).

${ }^{34}$ Kaza yapan gemilerin seyir halindeki diğer gemilere de zarar vermesi, kazaların bir diğer boyutudur. Örneğin, 14 Aralık 1960 tarihinde, Yunan Corld Harmony adlı tanker ile Yugoslav Petar Zoraniç adlı tanker Bebek önlerinde çarpıştıktan sonra Beykoz açıklarına sürüklenmişlerdi. Bu kazada her iki gemiden 52 kişi ölmüş, çıkan yangın İstinye önlerinde demirli "Tarsus" yolcu gemisine de sıçramış ve bu gemiyi de yakmıştır (Tercüman, 16.11.1979: 12)
} 
olduğu tahmin edilen 160 tonluk parça ortaya çıkmıştır. Tankerin enkazını kaldıran armatör, bu parçanın patlama sırasında gemiden $400 \mathrm{mt}$. uzağa firlayan üst güverte olduğu yorumunda bulunmuştur. Enkaz kaldırma işinde 4. ve son firma olduklarını söyleyen yetkili, kopan 160 tonluk parçanın kuma gömüldüğü için bulunamadığını ifade etmiştir (Milliyet, 16.5.2002: 17).

\section{Sonuc}

"İstanbul İstanbul olalı böyle dehşet, böyle korku, böyle panik yaşamadı" denilen İndependenta-Evriali kazası, İstanbul Boğazı'ndaki açık ara en büyük deniz kazası ve dünyadaki sayılı petrol yayılması vakalarından bir tanesidir. Aslında çok daha feci şekilde sonuçlanabilecek ve hatta birçok sivilin de ölmesine neden olabilecek kaza, talihin yardımıyla olabilecek en hafif şekilde atlatılmış, Yunan denizcilerin hepsi kurtulurken, Rumen denizcilerin ise neredeyse tamamı hayatını kaybetmiştir.

Bu kazanın birçok boyutu vardır; kazanın meydana gelme nedeni, kaza sonucu oluşan yangına müdahale edilememesi, enkazın yıllarca denizin ortasında kalarak tehlike yaratmaya ve çevreyi kirletmeye devam etmesi, kazadan etkilenenlerin maddi kayıpları ve bunların tazmin edilmesi, gemi ve özellikle büyük tankerlerin Boğazlardan böylesine kuralsız ve lakayt geçişleri, bu geçişlerin Montrö Boğazlar Sözleşmesi maddelerini tekrar gündeme getirmesi.

Yunan kaptan ve mürettebatın aksini iddia etmelerine rağmen kazaya hangi tarafın hatasının yol açtığı, bilirkişi tespitleri ve mahkeme sürecinde ortaya çıkmıştır, kazaya "Evriali" neden olmuştur. Fakat ağır bedeli kaybettiği hayatlarla "İndependenta" ödemiştir. Kazanın gerçekleştiği yer olarak Boğaz, Marmara Denizi ve İstanbul'da, hem insan hayatının tehlikeye girmesi, hem çevre kirliliği yaşanması, hem de yanan tanker enkazının insanlarda yarattığı korku ve tedirginlik kalıcı izler bırakmıştır. Kazanın anında hissedilen maddi-manevi sonuçları olduğu gibi, uzun yıllara yayılarak devam edegelen zararları da olmuştur. Hemen görülen etkiler bir aya yakın petrol yayılması ve yangın ile bunun yarattığ 1 tedirginlik, trafikteki aksamalar ve belirsizlikken; uzun vadede petrol yayılmasının yarattı̆̆ çevre kirliliği etkili olmuştur. Hem o zamanın imkânları hem de şimdi üstünden bunca zaman geçtikten sonra kazanın yarattığı çevre kirliliğinin boyutlarını tahmin etmek mümkün olmamış fakat denize yayılan petrol miktarının çokluğu verilen zararın çok büyük olduğunun ispatı sayılmıştır.

Patlamalardan, Topkapı Sarayı, Sultanahmet Camii ve Haydarpaşa Garı gibi çok önemli tarihi eserler zarar görmüştür. Kazanın kendisi gibi yangının sönmesi de şans eseri hava şartlarının iyi olmasının yardımıyla ve kendiliğinden olmuştur. Bu süreçte tüm dünyada olduğu gibi bu tip kazalara karşı hazırlıksız ve teknik yetersizlik içinde olan resmi merciler, gerekli müdahaleleri yapamamışlardır. İki gemi de İngiliz şirketlerince sigortalanmış olduğundan, özellikle Rumen gemisinin kendi sigorta şirketini harekete geçirmesi ve Türk Hükümeti’nin vinç getirmesi enkazın kaldırılmasında faydalı olmuştur. Kazada asıl suçlu Yunan şilebi ve mürettebatı olmakla birlikte, bunların süreçte herhangi bir katkı ve yardımları olmamıştır.

Bu kazadan sonra iki önemli değişiklik yapılmıştır. Birincisi, tüm dünyada denizlerdeki trafik akış1 sağdan olduğundan ve uzmanlarca bu yönde tavsiyeler verildiğinden, kazadan sonra İstanbul Boğazı'ndaki trafik akışında 1982 yılından itibaren "sağ seyir düzeni” ne geçilmesidir. İkincisi 1994 yılında, deniz yolculuğunun güvenliğini arttırmak, hayatları, deniz ortamını ve mülkleri korumak için çıkarılan “Boğazlar ve Marmara Bölgesi Deniz Trafik Düzeni Hakkında Tüzük”tür.

Türkiye'nin bu tür kazalara karşı sigorta olacak Brüksel Konvansiyonu'na girmemiş olması, büyük bir hata olarak görülmüştür. Bu kaza bir farkındalık yaratarak hem bu tür uluslararası anlaşmaların hem de Montrö Boğazlar Sözleşmesi'nin gündeme gelip sorgulanmasına yol açmıştır. $\mathrm{Bu}$ tartışmalarda bir taraf bu anlaşmanın gündeme getirilmesini gereksiz ve tehlikeli bulurken, diğer taraf anlaşmanın imzalandığı dönemle kazanın olduğu yıl arasında birçok açıdan değişiklik olduğundan hareketle Türkiye'nin çıkarlarını korumak için bunun kaçınılmaz olduğunu 
savunmuşlardır. Tabi bu anlaşma yerel bir anlaşmadır, böylesine önemli bir konuda olumlu ve kalıcı bir adım atabilmek için başta IMCO, TOVALOP (Dünya Tanker Donatanları Birliği) ve Birleşmiş Milletler gibi uluslararası kuruluşlarla görüşerek işbirliği yapmak faydalı olacaktır. Dönemin şartlarında Türkiye ve Karadeniz'e kıyı devletlerin iyiliği ve lehine olarak düzenlenen Montrö Boğazlar Sözleşmesi’ne rağmen Boğazlarla ilgili bazı güvenlik sorunları halen devam etmektedir.

\section{Kaynakça}

\section{Süreli Yayınlar}

Barış

Bugün

Cumhuriyet Senatosu Tutanak Dergisi

Die Zeit

Die Welt

Hürriyet

International Herald Tribune

Milliyet

Resmî Gazete

TBMM Genel Kurul Tutanağ 1

Tercüman

The Times

\section{Telif ve Tetkik Eserler}

Akten Necmettin, (2002). "The Bosphorus: Factors Contributing to Marine Casualties", Turkish J. Marine Sciences, 8, 179-195.

Akten, Necmettin, (2003). "The Strait of Istanbul (Bosphorus) : The Seaway Separating The Continets With Its Dense Shipping Traffic", Turkish J. Marine Sciences 9(3), 241-265.

Birpınar Mehmet E., Gonca F. Talu, Gönül Su, Mehmet Gülbey, (2006). "The Effect of Dense Maritime Traffic On The Bosphorus Strait And Marmara Sea Pollution", BALWOIS 2006 Conference on Water Observation and Information System for Decision Support, May 2326, Ohrid, Republic of Macedonia, 1-11.

Buhur, Sançar, (2007). “İstanbul Boğazı'ndaki Tehlikeli Yük Taşımacılığının Ön ve Geri Görünüm Sınırlarında Risk Altında Bıraktığı Bölgelerin Belirlenmesi”, İstanbul Teknik Üniversitesi, Fen Bilimleri Enstitüsü, Yüksek Lisans Tezi.

Ciachir, Nicolae, (2002). "Atatürk Döneminde Türkiye-Romanya İlişkileri”, Çev. Çağlar Enneli, Türkler Ansiklopedisi, 16. Cilt, Yeni Türkiye Yayınları, s. 654-660.

Çiçek, Kadir, (2018). "International Convention On Oil Pollution Preparedness, Response And CoOperation (OPRC) 1990 And Its Applications Related With Oil Spill In Turkey”, Oil Spill Along The Turkish Straits Sea Area; Accidents, Environmental Pollution, Socio-Economic Impacts And Protection, Ed.: Selma Ünlü, Bedri Alpar, Bayram Öztürk, Turkish Marine Research Foundation, s. 381-391. 
Doğan, Ertuğrul, Selmin Burak, (2007). "Ship-Originated Pollution in the Istanbul Strait (Bosphorus) and Marmara Sea", Journal of Coastal Research, Vol. 23, No. 2, Coastal Education \& Research Foundation, 388-394.

Erkebay, Şebnem, (2018). "International Convention Relating To Intervention On The High Seas In Cases Of Oil Pollution Casualties (Intervention 1969) And Its Applications Related With Oil Spill In Turkey", Oil Spill Along The Turkish Straits Sea Area; Accidents, Environmental Pollution, Socio-Economic Impacts And Protection, Ed.: Selma Ünlü, Bedri Alpar, Bayram Öztürk, Turkish Marine Research Foundation, 371-380.

Ekşi, Nuray, (2017). "Montreux Antlaşması Uyarınca Boğazlardan Geçen Yabancı Gemilerin Haczi ve Bu Gemilere El Konulmas1," Public and Private International Law Bulletin, 37(1), 125184.

Gürsoy, Umur, (2004). Enerjide Toplumsal Maliyet ve Temiz ve Yenilenebilir Enerji Kaynaklarl, Türk Tabipleri Birliği Yayınları.

Güven, Kasım Cemal, (2006). Oil Pollution In The Black Sea And Turkish Straits, The Turkish Straits: Maritime Safety, Legal and Environmental Aspects, (ed. Nilüfer Oral, Bayram Öztürk), TÜDAV yay., Yayın No: 25, 135-160.

İstikbal, Cahit, (2006). "Turkish Straits: Difficulties and The Importance of Pilotage", The Turkish Straits: Maritime Safety, Legal and Environmental Aspects, (ed. Nilüfer Oral, Bayram Öztürk), TÜDAV yay., Yayın No: 25, 66-80.

Jernelöv, Arne, (2010). "The Threats From Oil Spills: Now, Then, and in The Future", Ambio, Vol. 39, No. 5/6, 353-366.

Kurumahmut Ali, (2006). "The Montreux Convention, The Turkish Straits and The Black Sea", The Turkish Straits: Maritime Safety, Legal and Environmental Aspects, (ed. Nilüfer Oral, Bayram Öztürk, TÜDAV yay., Yayın No: 25, 16-21.

Kutluk, Deniz, (2003). Hazar-Kafkas Petrolleri, Türk Boğazları, Çevresel Tehdit, Türk Deniz Araştırmaları Vakfi Yayınları.

Küçükyıldız, Melik Çağrı, (2014). Petrol Tankeri Kazalarının Deniz Çevresine Etkileri Ve Tazmin Sistemi, Denizcilik Uzmanlık Tezi, Ulaştırma, Denizcilik Ve Haberleşme Bakanlığı, Deniz Ticareti Genel Müdürlüğü.

Orakçı, Salih, (2006). "General Directorate of Coastal Safety And Salvage Administration", The Turkish Straits: Maritime Safety, Legal and Environmental Aspects, (ed. Nilüfer Oral, Bayram Öztürk, TÜDAV yay., Yayın No: 25, 52-65.

Oral, Nilüfer, (2006). "The Turkish Straits and The IMO: A Brief History, Introduction”, The Turkish Straits: Maritime Safety, Legal and Environmental Aspects, (ed. Nilüfer Oral, Bayram Öztürk, TÜDAV yay., Yayın No: 25, 22-29.

Öz M. İdil, Nazlı Demirel, (2018). "The Anticipated Effects Of Oil Spill On Fish Populations In Case Of An Accident Along The Turkish Straits System- A Review of Studies After Several Incidents From The World", Oil Spill Along the Turkish Straits Sea Area; Accidents, Environmental Pollution, Socio-economic Impacts and Protection, Publisher: Turkish Marine Research Foundation Press, 261-271.

Öztürk Bayram, Özkan Poyraz, Elif Özgür, (2006). "The Turkish Straits: Some Considerations Threats and Future", The Turkish Straits: Maritime Safety, Legal and Environmental Aspects, (ed. Nilüfer Oral, Bayram Öztürk, TÜDAV yay., Yayın No: 25, 116-134. 
Öztürk, Bayram, Esra Billur Balcığlu, (2017). "Notes On The Fisheries Compensation For The Independenta/Evriali Incident In The Istanbul Strait, Turkey", J. Black Sea/Mediterranean Environment, 23(2), 187-190.

Rozakis, Christos L., Petros N. Stagos, (1987). International Straits of the World, The Turkish Straits, (ed. Gerard J. Mangone), Martinus Nijhoff Publishers.

Salihoğlu, Eren, (2017). Istanbul Boğazı Denizyolu Taşımacılı̆̆ının İş̧ Güvenliği Açısından İncelenmesi, Kocaeli Üniversitesi Fen Bilimleri Enstitüsü, Yüksek Lisans Tezi.

Soysal, İsmail, (2005). “Montrö Boğazlar Sözleşmesi”, İslam Ansiklopedisi, Cilt 30, Türkiye Diyanet Vakfi Yayınları, 274-276.

Taşkın Ergün, Barış Akçalı, (2018). "The Effects Of Oil Spill On The Macrophytobenthic Communities", Oil Spill Along The Turkish Straits Sea Area; Accidents, Environmental Pollution, Socio-Economic Impacts And Protection, (ed.: Selma Ünlü, Bedri Alpar, Bayram Öztürk), Turkish Marine Research Foundation, 244-252.

Topakoğlu, Levent, (2004). İstanbul Boğazı'nda Deniz Yolu İle Petrol Taşımacılı̆̆ının Çevresel Risk Değerlendirmesi, İstanbul Teknik Üniversitesi, Fen Bilimleri Enstitüsü, Çevre Bilimleri ve Mühendisliği, Yüksek Lisans Tezi.

Usluer Hasan Bora, Güler Bilen Alkan, (2016). "Importance of the Marine Science and Charting About Environmental Planning, Management and Policies at the Turkish Straits", EJSDR, European Journal of Sustainable Development Research, 1(1), 16-25.

Usluer Hasan Bora, Saim Oğuzülgen, (2018). "Remarkable Accidents At The Istanbul Strait", Oil Spill Along The Turkish Straits Sea Area; Accidents, Environmental Pollution, SocioEconomic Impacts And Protection, (ed.: Selma Ünlü, Bedri Alpar, Bayram Öztürk), Turkish Marine Research Foundation, 3-15.

Ülker Duygu, Sencer Baltaoğlu, (2018). "Ship Born Oil Pollution In Turkish Straits Sea Area And Marpol 73/78", Oil Spill Along The Turkish Straits Sea Area; Accidents, Environmental Pollution, Socio-Economic Impacts And Protection, (ed.: Selma Ünlü, Bedri Alpar, Bayram Öztürk), Turkish Marine Research Foundation, 363-370.

Ünlü, Selma, (2018). "Oil Pollution At Sea And Coast Following Major Accidents", Oil Spill Along The Turkish Straits Sea Area; Accidents, Environmental Pollution, Socio-Economic Impacts And Protection, (ed.: Selma Ünlü, Bedri Alpar, Bayram Öztürk), Turkish Marine Research Foundation, 101-120.

Yücesan, Osman, (1980). “Independenta-Evriali Çatışması”, Sigorta Dünyası, Y11 21, Say1 241, 67.

\section{İnternet Kaynakları}

http://www.itopf.org/in-action/case-studies/case-study/independenta-boshporus-turkey-1979/, E.T. 23.12.2019.

http://www.marinarii.ro/nave-de-istorie.php?id=2\&name=Nava_Independenta, E.T.: 11.12.2019. 


\section{Ekler}

Ek-1.

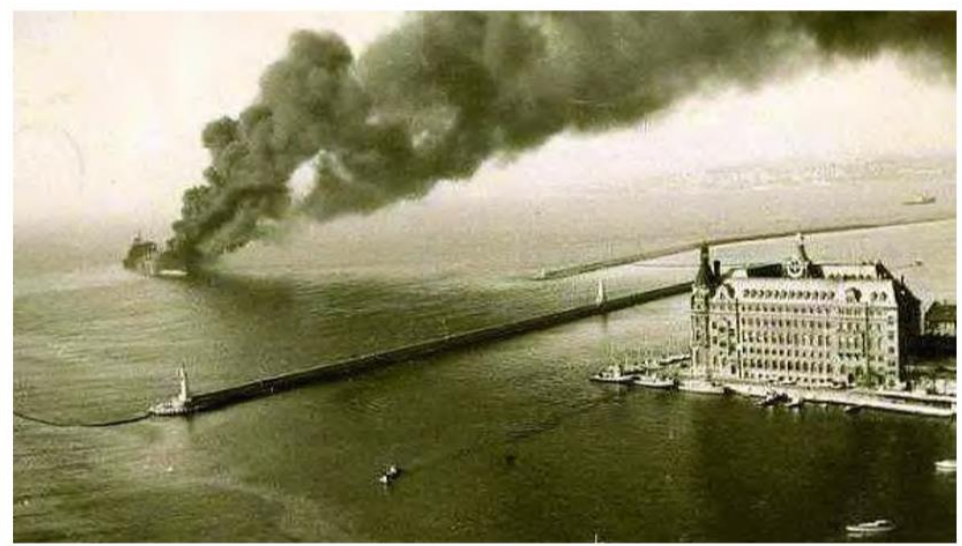

Oil Spill Along The Turkish Straits Sea Area; Accidents, Environmental Pollution, Socio-Economic Impacts And Protection, (2018). (ed.: Selma Ünlü, Bedri Alpar, Bayram Öztürk), Turkish Marine Research Foundation, s. 8.

Ek-2. "İstanbul Boğazı ve Marmara Denizi'ndeki en büyük deniz kazalarının yerleri; 1, Nassia; 2, Independenta; 3, Volgoneft-248."

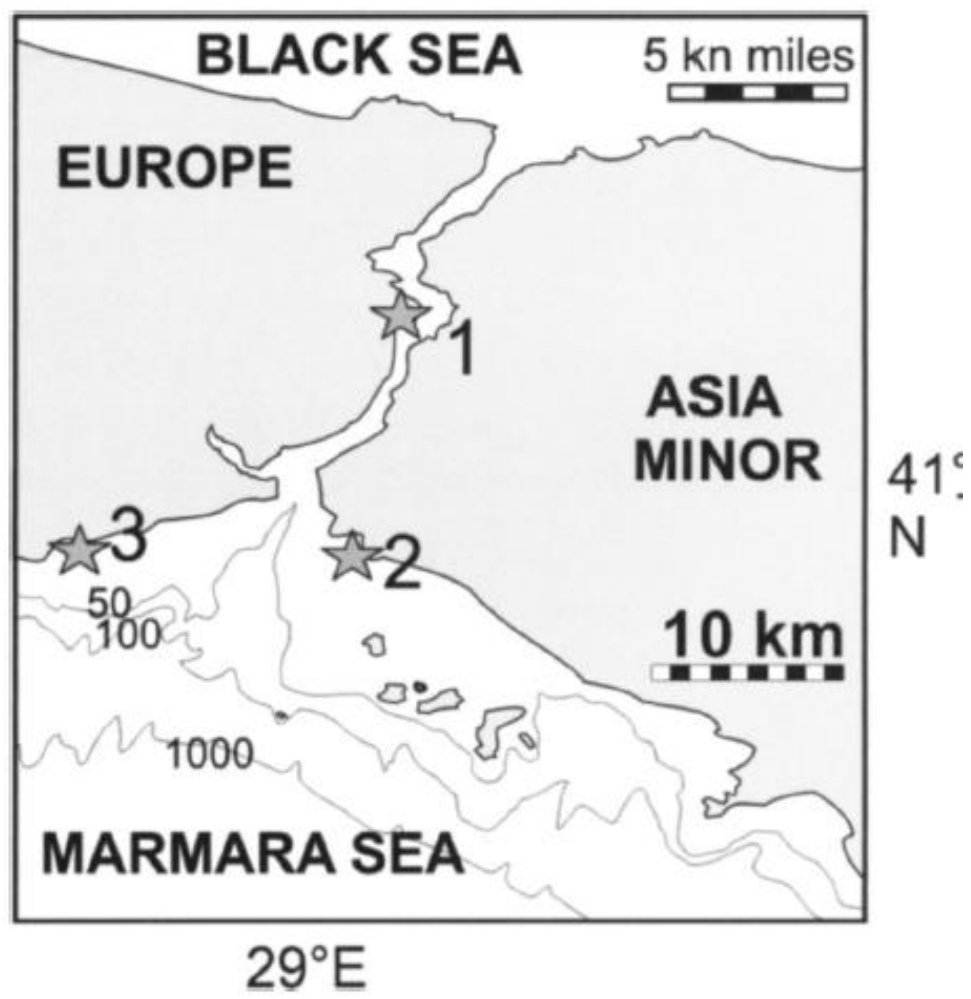

Ertuğrul Doğan, Selmin Burak, (2007). "Ship-Originated Pollution in the Istanbul Strait (Bosphorus) and Marmara Sea", Journal of Coastal Research, Vol. 23, No. 2, Coastal Education \& Research Foundation, s. 391. 
Ek-3.

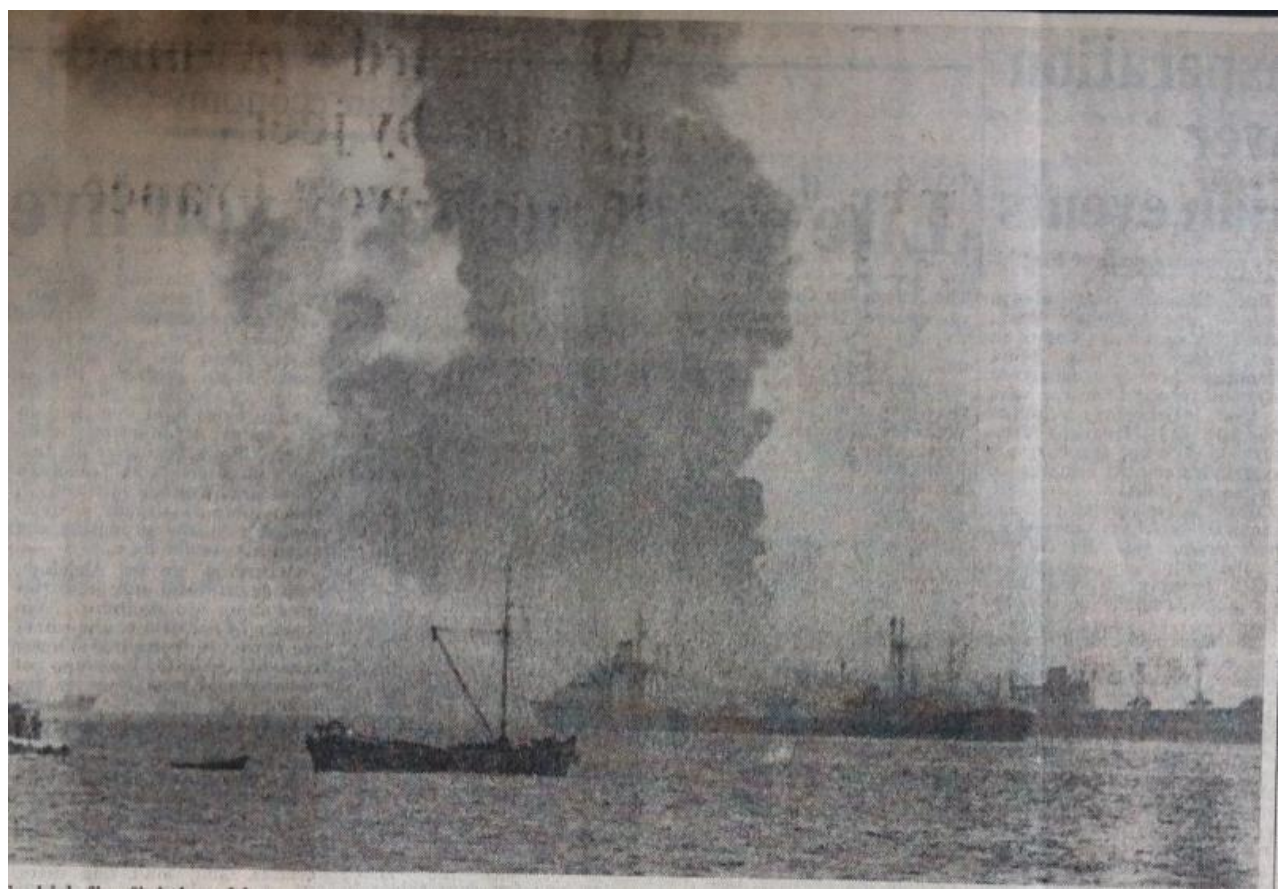

“50 On Ship Missing”, The Times, 16 November 1979, s. 7.

\section{Ek-4.}

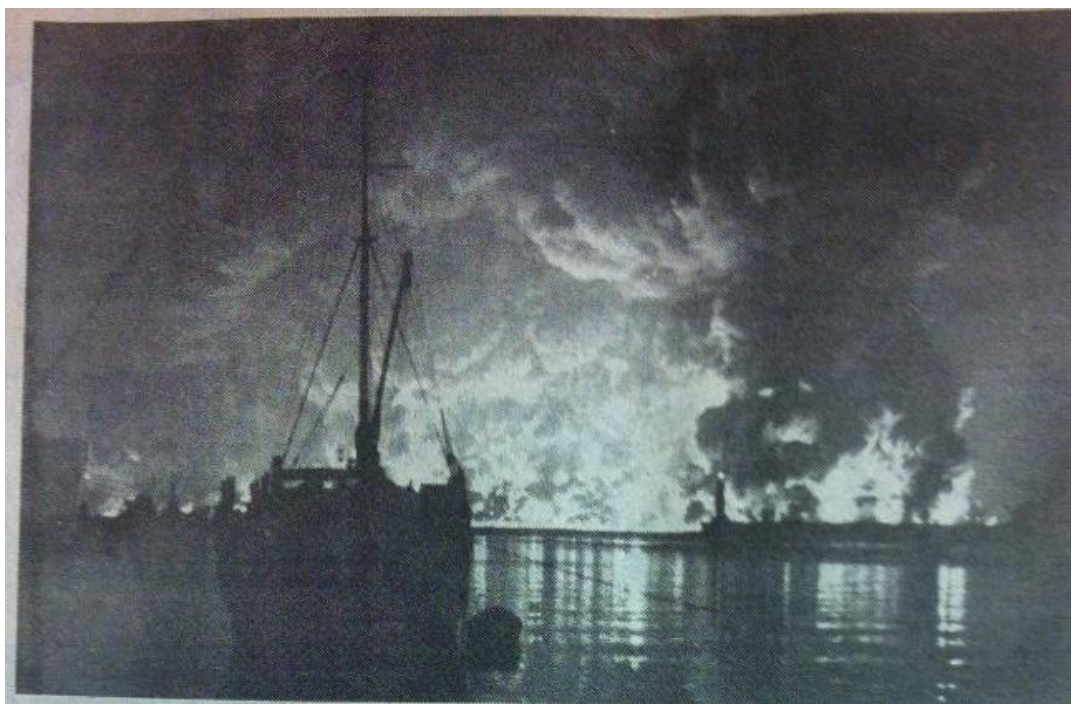

“2 Ships Collide In Turkey; 53 Said To Die”, International Herald Tribune, 16 November 1979, s. 2. 


\section{Ek-5.}

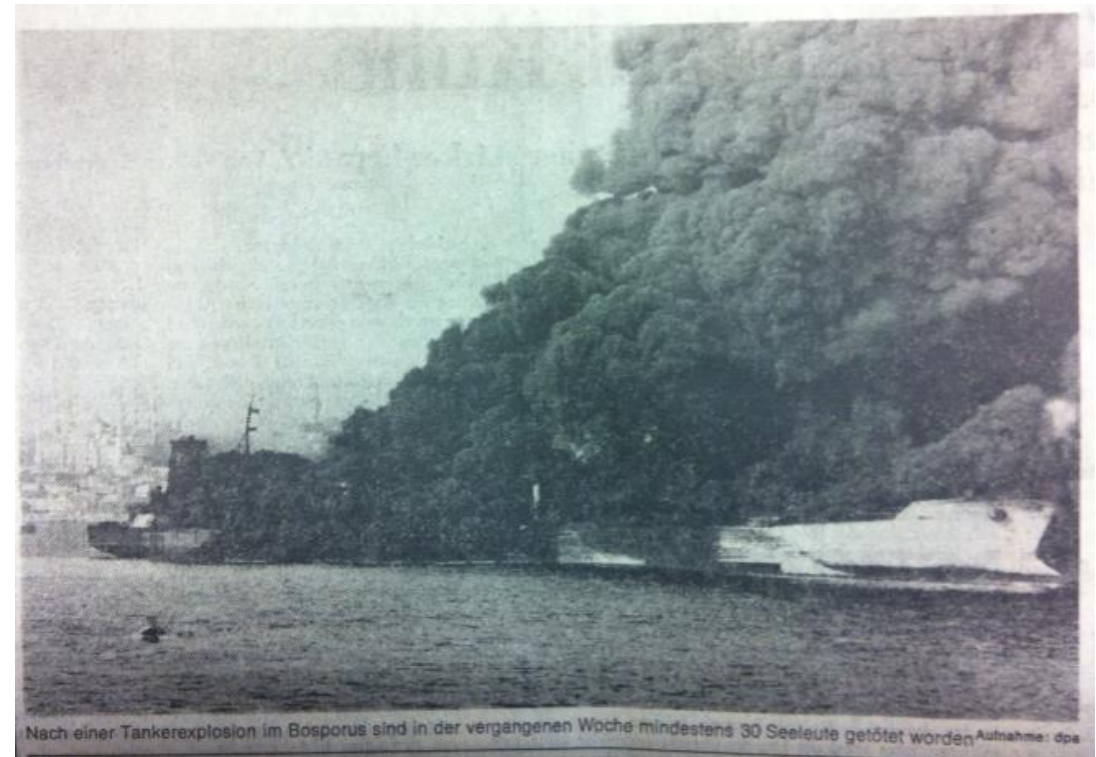

"Nach Einer Tankerexplosion im Bosporus Sind in der Vergangenen Woche Mindestens 30 Seeleute Getötet Worden", Die Zeit, 23 November 1979, s. 8. 